\title{
TAKING WHAT THEY GIVE US: EXPLAINING THE COURT'S FEDERALISM OFFENSIVE
}

\author{
KEITH E. WHITTINGTON†
}

\section{INTRODUCTION}

For several years now, the Supreme Court has disquieted observers and commentators by reasserting the presence of constitutional limitations on national power resulting from the federal structure of the American political system. Although not quite amounting to a revolution in American constitutional law, the recent federalism cases are nonetheless striking. ${ }^{1}$ They are, of course, most remarkable because they reverse over fifty years of nearly uninterrupted deference to the national government in matters relating to federalism and the structural limits on the powers of the central government. With the exception of an ill-fated attempt to identify such limits in 1976, under the guidance of then-Associate Justice William Rehnquist, ${ }^{2}$ the

Copyright (c) 2001 by Keith E. Whittington.

$\dagger$ Assistant Professor of Politics and John Maclean Jr. Presidential Preceptor, Princeton University. This Essay is a response to Christopher H. Schroeder, Causes of the Recent Turn in Constitutional Interpretation, 51 DUKE L.J. 307 (2001), presented at the Constitution in Exile conference hosted by the Program in Public Law at Duke University School of Law on October 5-7, 2000. Thanks to the participants of the conference, especially Christopher Schroeder, for their helpful discussion and comments. The author gratefully acknowledges the financial support of the John M. Olin Foundation during the preparation of this paper.

1. See, e.g., United States v. Morrison, 529 U.S. 598, 607-27 (2000) (holding that Congress lacks the authority to provide civil remedies for gender-motivated violence); Kimel v. Fla. Bd. of Regents, 528 U.S. 62, 80-91 (2000) (holding that Congress lacks the authority to abrogate state immunity against disability discrimination lawsuits); Alden v. Maine, 527 U.S. 706, 754 (1999) (holding that Congress lacks the authority to abrogate state sovereign immunity from lawsuits in state courts).

2. Nat'l League of Cities v. Usery, 426 U.S. 833, 854-55 (1976) (Rehnquist, J.) (holding that Congress lacks the authority to interfere with traditional state governmental functions). The decision in National League of Cities was overturned in Garcia v. San Antonio Metropolitan Transit Authority, 469 U.S. 528, 537-47 (1985). As Justice Brennan predicted in dissent, the decision would "astound" and dismay constitutional scholars. Nat'l League of Cities, 426 U.S. at 862 (Brennan, J., dissenting); see, e.g., Sotirios A. Barber, National League of Cities v. Usery: New Meaning for the Tenth Amendment, 1976 Sup. CT. REV. 161, 164 ("Without a doubt the decision will be roundly condemned by constitutional scholars."); Laurence H. Tribe, Unravel- 
post-New Deal Court had carefully refrained from giving judicial teeth to the idea that the national government was one of enumerated powers.

In recent years, the Rehnquist Court has signaled its seriousness about federalism. It has acted on the issue not once, but repeatedly, over nearly a decade. ${ }^{3}$ Moreover, the Court has not limited its focus to a single doctrine or aspect of federalism, but rather has opened multiple fronts to be prosecuted simultaneously. ${ }^{4}$ Perhaps most notably, the Court has even been willing to return to service an old warhorse from pre-New Deal campaigns: the Commerce Clause. ${ }^{5}$ The Court's concern with federalism has contributed significantly to a historically unprecedented spate of federal legislation being struck down as unconstitutional. In sharp contrast to most of its predecessors, the Rehnquist Court has trained nearly as much of its activist fire on its

ing National League of Cities, 90 HARV. L. REV. 1065, 1066 (1977) ("I make no claims about what the Justices [in National League of Cities] intended or 'really had in mind.' I haven't a clue what that might have been ....").

3. See Bd. of Trs. of the Univ. of Ala. v. Garrett, 531 U.S. 356, 121 S. Ct. 955, 962 (2001) (holding that suits against states under the Americans with Disabilities Act are barred by the Eleventh Amendment); Solid Waste Agency v. United States Army Corps of Eng'rs, 531 U.S. 159, 166-74 (2001) (interpreting the Clean Water Act in light of federalism concerns); Morrison, 529 U.S. at 607-19 (holding that Congress lacked the authority under the Commerce Clause to provide civil remedies for gender-motivated violence in the Violence Against Women Act); Kimel, 528 U.S. at 82-83 (holding that suits against states under the Age Discrimination in Employment Act are barred by the Eleventh Amendment); Alden, 527 U.S. at 741-54 (holding that suits against states under Article I legislation are barred by the Eleventh Amendment); Coll. Sav. Bank v. Fla. Prepaid Postsecondary Educ. Expense Bd., 527 U.S. 666, 691 (1999) (holding that the Trademark Remedy Clarification Act was not a valid abrogation of state sovereign immunity); Printz v. United States, 521 U.S. 898, 935 (1997) (holding that the federal government may not commandeer state officials); City of Boerne v. Flores, 521 U.S. 507, 534-36 (1997) (holding that portions of the Religious Freedom Restoration Act exceeded congressional authority under Section 5 of the Fourteenth Amendment); Seminole Tribe v. Florida, 517 U.S. 44, 72-73 (1996) (holding that suits against states under the Indian Gaming Regulatory Act are barred by the Eleventh Amendment); United States v. Lopez, 514 U.S. 549, 566-68 (1995) (holding that Congress lacked the authority under the Commerce Clause to regulate gun possession in school zones under the Gun-Free School Zones Act); New York v. United States, 505 U.S. 144, 174-77 (1992) (holding that a section of the Low-Level Radioactive Waste Policy Amendments Act was invalid because it either violated the Tenth Amendment or went beyond the scope of Congress's enumerated powers); Gregory v. Ashcroft, 501 U.S. 452, 463-64 (1991) (holding that the application of the Age Discrimination in Employment Act to state judges violated the Tenth Amendment).

4. In the past decade, the Court has expanded the Commerce Clause and the Tenth Amendment as limits on federal authority, barred the "commandeering" of state government officials by the federal government, and narrowed congressional authority under Section 5 of the Fourteenth Amendment. See supra note 3.

5. See Morrison, 529 U.S. at $607-19$ (holding that there is no congressional authority over local, noneconomic, criminal activity); Lopez, 514 U.S. at 552-67 (same). 
fellow coordinate branches of the federal government as on the relatively powerless states and localities.

The Court's actions raise any number of problems and puzzles. Not least among those puzzles is the matter of explaining why the Court has taken this course. Of course, it is possible to develop a purely jurisprudential explanation that would conclude that the Court has taken these actions simply because the Constitution, properly interpreted, compelled it to do so when faced with the type of legislation at issue in these cases. Without question, the jurisprudential explanation would be complicated and controversial. ${ }^{6}$ The text of the Constitution has not changed in regard to federalism during this period, and the statutes that the Court has examined generally have not been especially innovative. What has changed is not the Constitution or the laws, but the Court's understanding of the Constitution. If the Court has reached the correct judicial answers to these constitutional questions only recently, then it remains to be explained why this Court is willing or able to get these cases right when previous Courts were not. A jurisprudential explanation of the Court's recent federalism offensive will have to be supplemented with a political explanation. Although the political investigation need not be hostile to the jurisprudential one, this Essay will limit itself to the former.

The federalism offensive can best be understood as a product of the Court's taking advantage of a relatively favorable political environment to advance a constitutional agenda of particular concern to some individuals within the Court's conservative majority. The Court has moved carefully but steadily to reestablish some federalism-based constraints on the national government. The exercise of the power of judicial review striking down acts of Congress, and on federalism grounds no less, ${ }^{7}$ immediately evokes images of the Lochner-era ${ }^{8}$

6. For jurisprudential critiques of the Court's federalism offensive, see, for example, Daniel J. Meltzer, State Sovereign Immunity: Five Authors in Search of a Theory, 75 NOTRE DAME L. REV. 1011, 1038-63 (2000) (discussing the role of state dignity and sovereignty in recent federalism cases); H. Geoffrey Moulton, Jr., The Quixotic Search for a Judicially Enforceable Federalism, 83 MinN. L. REV. 849, 850-51 (1999) (tracing the Supreme Court's search for an enforceable principle of federalism from the New Deal to Lopez and concluding that "lines drawn in Lopez, New York, and Printz are unsupported by constitutional text, structure or history"); Herman Schwartz, The Supreme Court's Federalism: Fig Leaf for Conservatives, 574 ANNALS AM. ACAD. POL. \& SOC. SCI. 119, 123-29 (2001) (questioning the motives behind the recent surge of federalism cases defending states' rights).

7. See supra note 3 .

8. "Lochner-era" refers to the first decades following the Supreme Court's decision in Lochner v. New York, 198 U.S. 45, 64 (1905) (invalidating a New York labor law as violative of 
Court's pitched battles with the Roosevelt administration over the New Deal and the Court's ultimate humiliation. ${ }^{9}$ The analogy is misplaced, however. This Court is not in the same position or pursuing the same strategy as the Lochner-era Court, and it is much more likely that the Court will be able to maintain its current efforts without significant political costs. In considering the Court's federalism offensive, Part I of this Essay lays out two approaches within the political science literature for explaining Supreme Court decisionmaking. Part II considers Bruce Ackerman's theory of constitutional moments as an explanation for the recent transformations of the federalism jurisprudence. Part III builds on the new institutionalist school of analysis to help explain the recent federalism revival.

\section{POLITICAL APPROACHES TO JUdiCIAL DECISIONMAKING}

There is a substantial political science literature on judicial decisionmaking. ${ }^{10}$ This literature is concerned primarily with offering political (that is to say, nonjurisprudential) explanations for the decisions that the judiciary, and especially the Supreme Court, makes. This literature can be extremely useful, but it has to be approached with some caution. For one thing, political scientists are not always interested in explaining the same things as legal scholars. Not only are they likely to focus on a different set of explanations in which doctrine and legal arguments play a limited role, but also they are likely

an employee's Fourteenth Amendment right to freedom of contract).

9. After more than three decades of resistance to progressive legislation at the state and local level, the Court struck down central components of the New Deal on a variety of grounds, including federalism. In 1937, President Franklin Roosevelt proposed a judicial reform measure that would have expanded the size of the Supreme Court and allowed him to appoint a majority of its members. In the same year, the Court abruptly reversed course and gave its approval to new economic regulatory measures at the state and national level. For accounts of this period, see generally BARRY CUSHMAN, RETHINKING THE NEW DEAL COURT (1998) (reevaluating the "switch-in-time" story as part of the history of ideas, rather than as a political encounter, thereby presenting an alternative reason for the change and using that reason to analyze the famous New Deal cases); Howard Gillman, THE Constitution Besieged (1993) (describing the origins of and reaction to the Lochner era in terms of police power jurisprudence); WILLIAM E. Leuchtenburg, The Supreme Court Reborn (1995) (outlining three key pre-1937 cases, the Court-packing plan, and the resulting emergence of the "Second Bill of Rights" through the incorporation doctrine).

10. See generally LAWrence Baum, The Puzzle of Judicial Behavior (1997) (assessing the state of current analysis of judicial behavior and calling for more diverse research);

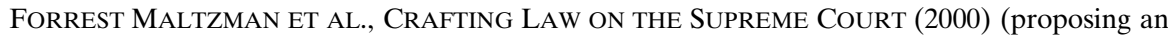
interactive model of Supreme Court decisionmaking in which Justices use various signals to influence their colleagues' decisions); Terri Jennings Peretti, In DEFEnSE of a Political COURT 80-132 (1999) (summarizing political science judicial decisionmaking literature). 
to focus on different objects of explanation. The outcomes of particular cases or the substantive content of particular opinions are likely to fall outside the scope of political science analysis, which is more concerned with general patterns. From a legal perspective, political science explanations of court behavior simply may not be very satisfying. For another thing, political scientists are not of one mind as to how best to understand the actions of the Supreme Court. Particularly in the 1960s, fierce debates raged between political scientists who primarily thought of the Court and the law in legal and normative theoretical terms and those who primarily thought of the Court in political and positivist terms. ${ }^{11}$ For a long period thereafter, the latter group was ascendant. Their primary product was what has become known as the "attitudinal model," which explains judicial outcomes in terms of the policy preferences of individual Justices. ${ }^{12}$ Recently, an alternative approach known as "new institutionalism" has become prominent. ${ }^{13}$ There are several variations of the new institutionalist approach, but they collectively emphasize the importance of the particular institutional environment of the Justices in affecting the Court's work. ${ }^{14}$ The approach may be particularly useful to help explain the Court's recent actions.

To some degree, essentially all political science approaches to judicial decisionmaking are "externalist," not "internalist," as Professor Christopher H. Schroeder defines those categories, in that political science approaches incorporate explanations that "are not based on

11. Compare Wallace Mendelson, The Neo-Behavioral Approach to the Judicial Process: A Critique, 57 AM. POL. SCI. REV. 593, 602-03 (1963) (criticizing the neo-behavioralist theory of judicial decisionmaking), with S. Sidney Ulmer, An Analysis of Behavior Patterns on the United States Supreme Court, 22 J. POL. 629, 652 (1960) (using behavioral explanations for judicial decisionmaking).

12. For the most comprehensive, recent defense of the attitudinal model, see JEFFREY A. Segal \& Harold J. Spaeth, The Supreme Court and the Attitudinal Model 356-63 (1993) (responding to several criticisms of the attitudinal model). For a recent critique of the attitudinal model, see Frank B. Cross, Political Science and the New Legal Realism: A Case of Unfortunate Interdisciplinary Ignorance, 92 Nw. U. L. REV. 251, 265-312 (1997).

13. For an introduction to new institutionalism as applied to the judiciary, see generally Supreme Court Decisionmaking (Cornell W. Clayton \& Howard Gillman eds., 1999) (analyzing the Supreme Court as an institution, the internal decisionmaking processes of the Court, and extrajudicial influences on Supreme Court decisionmaking).

14. The rational choice variant of new institutionalism is particularly concerned with strategic behavior by political actors in response to constraints and the use of political institutions to solve collective action and information problems. The historical variant of new institutionalism examines how institutions both regulate and constitute political preferences. Keith E. Whittington, Once More unto the Breach: PostBehavioralist Approaches to Judicial Politics, 25 L. \& Soc. INQUIRY 601, 608-16 (2000). 
anything "internal to the legal process itself." 15 Rather than being strictly dichotomous, internalist and externalist explanations exist on a spectrum of possible accounts of judicial decisionmaking. Attitudinal explanations would likely fall near the extreme externalist end of such a spectrum, since they minimize the importance of legal reasoning or doctrine in determining judicial outcomes. ${ }^{16}$ Other political science approaches to understanding judicial behavior, most notably the new institutionalist approaches, take internal features of the legal process more seriously. These approaches do not embrace the pure internalism of the legal idealist model, however. They instead offer the type of middle-ground argument that Professor Schroeder believes may be most useful for understanding and explaining legal change.

The attitudinal model views legal and constitutional change as a simple matter of counting votes on the Court. ${ }^{17}$ In any given case, the attitudinal model expects Justices to act so as to advance their preferred policies, regardless of such legal factors as precedent, statutory or constitutional text, or historical intent. ${ }^{18}$ Judges behave like any other political actors faced with making choices that have political and policy consequences. ${ }^{19}$ They act so as to advance their preconceived goals and reach the results that are most agreeable with their personal predispositions. ${ }^{20}$ The very institutional features designed to secure judicial independence (such as lack of electoral accountability) insure that the Justices can give their ideological preferences "free play" ${ }^{21}$ and "base their decisions solely upon personal policy preferences." 22 Although directly testing judicial adherence to the legal pro-

15. Christopher H. Schroeder, Causes of the Recent Turn in Constitutional Interpretation, 51 DukE L.J. 307, 327 (2001); see also CUSHMAN, supra note 9, at 4 (distinguishing the "internalist" and "externalist" explanations of the New Deal Court).

16. It might be noted that the attitudinalists use similar internalist-externalist terminology to nearly opposite effect. For attitudinalists, "internal" relates to the individual rather than to the law; thus, personal policy preference is an "internal" factor of judicial decisionmaking. By contrast, precedent or threat of political reprisals would both be "external" factors that might constrain the behavioral expression of the internal preference of the judge.

17. SEGAL \& SPAETH, supra note 12 , at $64-73,241-55$.

18. Id. at $64-65$.

19. Id. at $72-73$.

20. Id. at 214-55.

21. David W. Rohde \& Harold J. Spaeth, Supreme Court Decision Making 72 (1976).

22. Id. Those institutional features that support purely attitudinal behavior are strongest at the level of the Supreme Court. By contrast, lower federal judges may be constrained (to follow precedent, for example) by the prospect of higher court review and reversal. See, e.g., Charles 
cess is difficult, supporters of the attitudinal model have noted that Justices tend to vote in an ideologically consistent fashion over time regardless of the particular facts or legal issues raised in individual cases, and that simply knowing the past voting behavior of the Justices or even their ideological profile at the time of their nomination is sufficient to predict accurately their votes in future cases. ${ }^{23}$ Justices adhere to precedents only when they otherwise agree with them. When individual Justices disagree with a precedent, they ignore it. ${ }^{24}$ When a majority of the Justices disagree with a precedent, they abandon it. ${ }^{25}$ Constitutional law changes whenever five Justices who would prefer a different law land on the Court.

Strictly speaking, the attitudinal model no longer attempts to explain the origins of these policy preferences or the composition of the Court. ${ }^{26}$ Nonetheless, this account of decisionmaking on the Court is fully consistent with political science arguments emphasizing that judicial appointments follow the election returns. It should be emphasized that the attitudinal model implies that the Court as a whole only follows the election returns through the process of judicial replacement. ${ }^{27}$ Individual Justices will ignore electoral shifts and continue to vote their personal policy preferences, even if those policies have been rejected at the polls. ${ }^{28}$ Presidents and senators can be expected to select Justices who are sympathetic to their own ideological predispositions. As a consequence, the course of constitutional law can be

\footnotetext{
M. Cameron et al., Strategic Auditing in Political Hierarchy: An Informational Model of the Supreme Court's Certiorari Decisions, 94 AM. POL. SCI. REV. 101, 102-08 (2000) (proposing that appellate review acts as a mechanism for "enforcing doctrine" in a judicial bureaucracy); Frank B. Cross \& Emerson H. Tiller, Judicial Partisanship and Obedience to Legal Doctrine: Whistleblowing on the Federal Courts of Appeals, 107 YALE L.J. 2155, 2158-61 (1998) (suggesting that circuit court dissents act as signals for Supreme Court review).

23. Segal \& SPAETH, supra note 12 , at 214-55, 363.

24. See Harold J. Spaeth \& JefFrey A. Segal, Majority Rule or Minority Will 287-88 (1999) (arguing that Justices are rarely influenced by stare decisis).

25. See Christopher P. Banks, The Supreme Court and Precedent: An Analysis of Natural Courts and Reversal Trends, 75 JUdiCATURE 262, 265-68 (1992) (pointing to an increase in overturned precedent when ideological majorities are established).

26. In early versions, judicial "attitudes" were rooted in sociological and psychological theories. See, e.g., Glendon Schubert, THE Judicial Mind 22-43 (1965) (building on the theoretical work of social psychologists). Those efforts were not terribly successful in explaining the origins of judicial attitudes, and consistent with trends in economic theory, judicial preferences are now taken as a given.

27. For a classic statement of this thesis, see generally Robert A. Dahl, Decisionmaking in a Democracy: The Supreme Court as a National Policy-Maker, 6 J. PUB. L. 279 (1957).

28. Id. at $284-86$.
} 
expected over time to reflect electoral outcomes. ${ }^{29}$ Once this conclusion is reached, the political science analysis of the judiciary fades into the extensive literature on political parties and elections.

This literature can be extremely useful in clarifying aspects of the Court's behavior, especially in relation to the actions of the Justices over a large number of cases. Some of the political scientists' claims still are being contested on empirical grounds, while other empirical findings are still being interpreted. ${ }^{30}$ In the meantime, this type of analysis tells us only so much. In keeping with the central tendencies of empirical political science since the 1950s, the attitudinal model is concerned with observable, measurable, and politically effective individual behavior. ${ }^{31}$ As a purely externalist model of judicial decisionmaking, the attitudinal model has little to say about the subjective experience of judging or the substantive content of legal reasoning and judicial opinions. Although the externalist and internalist perspectives are often posited as offering competing explanations of judicial behavior, the real challenge is to bridge the gap between them to develop accounts that can reconcile the verifiable observations of the externalist explanations with the also significant empirical support for the internalist explanations. In part, this means understanding how the legal process internalizes the "external" stuff of politics.

New institutionalist accounts of judicial behavior are focused particularly on that issue, and Professor Schroeder's helpful analysis can be understood as a contribution to this growing literature. ${ }^{32}$ In particular, his historicist account of the social and intellectual context within which judicial doctrine is formulated is fully consistent with what has become known as historical or interpretive new institutionalism. In general, the new institutionalist approaches to politics

29. For an overview of this literature, see PERETTI, supra note 10, at 80-132.

30. See, e.g., Howard Gillman, What's Law Got to Do with It? Judicial Behavioralists Test the "Legal Model" of Judicial Decision Making, 26 LAW \& SOC. INQUIRY 465, 468-76 (2001) (discussing the behavioralists' limited analysis of legal variables in judicial decisionmaking); Jeffrey A. Segal, Supreme Court Deference to Congress: An Examination of the Marksist Model, in SUPREME COURT DECISIONMAKING, supra note 13, at 237, 240-53 (responding to game theory critiques of the attitudinal model).

31. DAVID M. Ricci, THE TRAGEDy OF POLITICAL SCIENCE 133-75 (1984) (discussing the behavioralist revolution in political science); RAYMOND SEIDELMAN \& EDWARD J. HARPHAM, Disenchanted Realists: POlitical SCIENCE AND THE AMERICAN CRISIS, 1884-1984, at 149-86 (1985) (same).

32. See Schroeder, supra note 15, at 324-25 (suggesting that explanations for judicial decisionmaking must account for political and social changes); see also Kathleen Thelen, Historical Institutionalism in Comparative Politics, 2 ANN. REV. POL. SCI. 369, 372-99 (1999) (presenting an overview of historical new institutionalism literature). 
broadly and to judicial politics specifically are concerned with investigating how the context within which political actors make decisions matters. ${ }^{33}$ The "institutional" environment, which encompasses procedural rules, other powerful actors, informal norms, intellectual discourses, and other features, may structure, constrain, or guide political decisions. ${ }^{34}$ For new institutionalism, the law matters to judicial behavior, even as the law itself is embedded within a larger social, political, and intellectual context. ${ }^{35}$ For rational choice new institutionalists (or the "positive theory of institutions"), the law primarily matters because of the sanctions that can come from violating it or the collective action benefits that it can facilitate. ${ }^{36}$ Judges may have political preferences, but they are constrained in their ability to pursue those preferences, and legal materials may be among those constraints. For historical new institutionalists, the law also may matter in socializing judges and creating new normative commitments (or preferences) that they will seek to realize. For attitudinalists, preferences are sincerely expressed. For rational choice new institutionalists, preferences often may be frustrated by external constraints. ${ }^{37}$ For historical new institutionalists, preferences often may be constituted by contextual forces. ${ }^{38}$ Judicial understandings of the Constitution grow

33. See Howard Gillman \& Cornell W. Clayton, Beyond Judicial Attitudes: Institutional Approaches to Supreme Court Decisionmaking, in SUPREME COURT DECISIONMAKING, supra note 13, at 1-7 (criticizing the attitudinal theory of Supreme Court decisionmaking); Forrest Maltzman et al., Strategy and Judicial Choice: New Institutionalist Approaches to Supreme Court Decisionmaking, in SUPREME COURT DECISIONMAKING, supra note 13, at 46-57 (discussing neoinstitutionalist theories of Supreme Court decisionmaking and external constraints on judicial action).

34. See Rogers M. Smith, Political Jurisprudence, the "New Institutionalism," and the Future of Public Law, 82 AM. POL. SCI. REV. 89, 92-99 (1988) (elaborating the incorporation of the institutional environment into political science).

35. See Whittington, supra note 14, at 619-26.

36. Lee Epstein \& JACK KNIGHT, The Choices Justices MaKe 12-18, 115-25, 145-57 (1998).

37. Id. at 12-17; Maltzman et al., supra note 33, at 48-57. Rational choice new institutionalist accounts are still externalist in Professor Schroeder's sense of the term, but less so than attitudinal accounts. They explain judicial outcomes in terms of policy preferences and strategic action relative to institutional constraints. Legal reasoning is purely instrumental (as a signal of constraint or as a means for circumventing constraints) rather than intrinsically valued or motivating in its own right. Id. at 52-57.

38. See Howard Gillman, The Court as an Idea, Not a Building (or a Game): Interpretive Institutionalism and the Analysis of Supreme Court Decisionmaking, in SUPREME COURT DECISIONMAKING, supra note 13, at 78-86 (discussing how the role of a Justice's "mission" as a Justice contributes to decisionmaking); Rogers M. Smith, If Politics Matters: Implications for a "New Institutionalism," 6 STUD. AM. POL. DEV. 1, 30-36 (1992) (proposing that political scien- 
out of a particular social, political, and intellectual environment. Although attitudinalist research can be very useful in identifying the preferences of judges, it generally is not very illuminating as to why those preferences developed or under what conditions they may be expressed and successfully realized in outcomes. ${ }^{39}$

\section{No PotTed Plant: JUdicial AGENCY AND COnstitutional CHANGE}

Identifying and explaining constitutional change is no easy task. There is a deep jurisprudential and normative resistance to recognizing constitutional "change" outside the formal amendment process, and once constitutional change is detached from formal constitutional amendment then it becomes an empirical challenge to recognize the timing, form, and substance of such change. ${ }^{40}$ One notable approach to understanding constitutional change is Bruce Ackerman's theory of constitutional moments, in which judges articulating constitutional law faithfully follow the constitutional transformations rendered in the external political arena. ${ }^{41}$ Although Ackerman's theory is extremely useful and stimulating, the recent federalism offensive suggests the limits of his theory as a comprehensive approach to constitutional change.

Assessing and applying Ackerman's theory is complicated by the fact that it is both positive and normative in its structure and aspirations. Ackerman not only wants to construct a positive theory that can account for constitutional change in American history, he also wants a normative theory that can justify and delimit those changes and guide the exercise of judicial review. Ackerman's interpretation of American constitutional history largely accomplishes both objectives at once, but more recent history, and in particular the possibility

tists should study the various institutions that empower, constrain, and define the way political actors function).

39. For a discussion of these approaches, see Whittington, supra note 14, at 617-32 (discussing theories of Supreme Court decisionmaking).

40. For a discussion of this resistance, see Sanford Levinson, How Many Times Has the United States Constitution Been Amended? (A) < 26; (B) 26; (C) 27; (D) > 27: Accounting for Constitutional Change, in RESPONDING TO IMPERFECTION 14-24 (Sanford Levinson ed., 1995) (discussing the distinction between interpretation and amendment).

41. See generally 1 Bruce Ackerman, We the People: Foundations (1991); 2 Bruce Ackerman, We the PeOple: Transformations (1998). 
of "transformative appointments" to the Court, ${ }^{42}$ calls attention to the tensions between these two strands of the theory. ${ }^{43}$ For present purposes, we can lay aside the normative dimension of Ackerman's theory and simply consider how well it works as a positive theory of constitutional change.

As Professor Schroeder notes, it is hard to argue that the recent string of federalism cases is simply an evolutionary extension of earlier precedents. ${ }^{44}$ Although in some instances the Court has been careful to emphasize some continuity with prior doctrine, ${ }^{45}$ there is little question that the Court's assertiveness on federalism over the past decade is quite distinct from its deference during earlier decades and that the hurdles that the Court is now throwing up against congressional action were not recognized as even existing ten years ago. Regardless of whether we characterize this as a change in the Constitution itself, it is at least true that there has been a significant discontinuity in the judicial interpretation and effective law of an important aspect of the Constitution. It is precisely such discontinuities in constitutional law that Ackerman's theory of constitutional change seeks to address. Substantively, we seem to have passed into a new "constitutional regime."

At the same time, we seem to have, at best, imperfectly experienced the procedural requirements of constitutional change that Ackerman's theory envisions. ${ }^{47}$ Most importantly, Ackerman posits

42. Ackerman labels appointments to the Supreme Court that are intended to revolutionize constitutional law as "transformative." Bruce A. Ackerman, Transformative Appointments, 101 HARV. L. REV. 1164, 1168-73 (1988).

43. 2 ACKERMAN, supra note 41, at 389-416. These tensions are examined further in Keith E. Whittington, From Democratic Dualism to Political Realism: Transforming the Constitution, 10 CONST. POL. ECON. 405, 411-12 (1999) (discussing the tension between Ackerman's normative and positive theories).

44. Schroeder, supra note 15 , at 317-22.

45. See, e.g., Alden v. Maine, 527 U.S. 706, 745-48 (1999) (relying on "settled doctrine"); United States v. Lopez, 514 U.S. 549, 553-59 (1995) (determining that the ruling was "consistent with the great weight of our case law").

46. 1 ACKERMAN, supra note 41 , at 59 . This is not to say that the posited constitutional regime is particularly significant, far-ranging, or enduring, in historical terms. The notion of a "regime" seems to imply all three, and Ackerman's own narrative focuses on constitutional changes of that sort, but that may simply indicate the limits of his particular approach.

47. Ackerman identifies four phases of "higher lawmaking": a signal of broad and deep popular support for constitutional reform, the articulation of an operational proposal, mobilized popular deliberation on and approval of the proposal, and legal codification of the proposal. 1 ACKERMAN, supra note 41, at 266-69; see also id. at 15-26 (using the four steps to explain the Reconstruction and the New Deal); Mark Tushnet, Living in a Constitutional Moment?: Lopez and Constitutional Theory, 46 CASE W. RES. L. REV. 845, 847 (1996) ("[W]e cannot be in a con- 
that the Court is not the active agent of constitutional change. ${ }^{48}$ The Court follows, and eventually codifies, the constitutional changes initiated elsewhere. Within Ackerman's constitutional moment, political actors signal their discontent with the Constitution as it is understood and enforced by the Court and mobilize popular support on behalf of a proposal to alter the inherited Constitution. ${ }^{49}$ Encountering a constitutional impasse, political actors sharpen their point of contention with the obstructionist institution and seek greater authority from the people. ${ }^{50}$ Receiving an electoral mandate, newly empowered actors then challenge the dissenting institution until the latter switches and the new position is consolidated through subsequent elections. ${ }^{51} \mathrm{Al}-$ though in recent elections some political actors have talked about constitutional issues, ${ }^{52}$ including federalism, ${ }^{53}$ it is difficult to identify any broad and deep popular (or even elite) deliberation on specific constitutional proposals or any decisive electoral acceptance of those proposals. The 2000 presidential election even may have helped continue, if not exactly consolidate, the Court's slim federalism majority, ${ }^{54}$ yet even to the extent that the campaigns touched on the $\mathrm{Su}$ preme Court they did not focus on federalism. The Court seems to be leading the constitutional charge relating to federalism, rather than

stitutional moment in Ackerman's terms."). More generally, however, Tushnet offers an accounting of Lopez that is sympathetic to Ackerman. Tushnet, supra, at 875 ("Ackerman's theory sheds light on recent constitutional developments even if it does not fully explain them.").

48. 1 ACKERMAN, supra note 41 , at $60-61$.

49. Id. at 266-67.

50. 2 ACKERMAN, supra note 41, at 18-20, 24.

51. Id. at 20 .

52. See, e.g., Ann McFeatters, Party Rallies Faithful, Liberal Rhetoric is Theme of Day for Democrats, PitTsBurgh Post-GAZETTE, Aug. 16, 2000, at A1 (reporting the stance on abortion rights and civil rights taken by Democratic leaders at the 2000 Democratic Convention); Gaylord Shaw, No School Prayer, High Court Says Prayer Led by Student Unconstitutional, NEWSDAY, June 20, 2000, at A5 (reporting statements made by Al Gore and George W. Bush on school prayer during the 2000 presidential campaign).

53. See, e.g., Norman Ornstein, New Federalism Not Without Faults, USA TODAY, Sept. 23, 1996, at 15A (reporting policy positions on federalism taken by Bob Dole and Bill Clinton in the 1996 campaign); Robynn Tysver, Bush Talks Civility at Chicago Gathering, OMAHA WORLDHeRALD, June 19, 2000, at 4 (reporting comments made by George W. Bush on the importance of states). But see Donald F. Kettl, Which One is Your Pal?, Governing, Aug. 2000, at 12 (stating that George W. Bush and Al Gore give "few real clues" of their stand on federalism issues).

54. If given the opportunity, President George W. Bush is likely to appoint another Justice favorably disposed to the federalism offensive. Given the ages of the current Justices, it seems unlikely that Bush will be able to expand the size of the current majority and thereby make it less vulnerable to future Democratic appointments. 
following a prior clear and authoritative expression of the popular will on the subject.

As an explanation for these constitutional changes, the Ackerman model seems inadequate. As Professor Schroeder notes, Ackerman's positive model of constitutional change must be incomplete: "[i]f revolutionary constitutional change has occurred, and if that change is legitimate, ... [ [t] here must be a causal process at work that is materially different from the one Ackerman posits." ${ }^{, 5}$ At the same time, however, Ackerman's rich historical narrative indicates that his model is useful for explaining at least some constitutional changes in the past. It is worth pausing to consider, therefore, why the model does not seem to work in this case.

Ackerman's model of constitutional moments ushering in new constitutional regimes is closely linked to political science theories of "critical elections," with the similar notion of extraordinary elections initiating significant political change and new political regimes. ${ }^{56}$ At one level, this connection is clearly an advantage. "Realignment," or critical election, theory is a major contender in studies of American political development, and Ackerman has opened a very fruitful interdisciplinary dialogue by looking to such theories and grounding constitutional theory within positive models of American politics and history. At another level, the theoretical convergence creates difficulties, as it exposes Ackerman's theory to many of the criticisms leveled at realignment theory while also raising concerns about the points at which Ackerman diverges from traditional theories of critical elections.

A few problematic elements, in particular, of Ackerman's reliance on critical election theory can be highlighted. First and most obviously, Ackerman emphasizes the importance of electoral shifts to provoking and realizing constitutional change. ${ }^{57}$ The "We the People" project is distinguished by the centrality, on both the positive and normative dimensions, of electoral mandates provided by an active and deliberate citizenry. ${ }^{58}$ These mandates provide elected officials with the political capital and authority that they need to act on their constitutional proposals, overcome political resistance, and institute

55. Schroeder, supra note 15 , at 322 .

56. Ackerman acknowledges his debt to critical election theory in 1 ACKERMAN, supra note 41 , at 329 n.1.

57. 2 ACKERMAN, supra note 41, at 186-88, 281-90, 306-12.

58. Id. at 12, 18-20, 67-68. 
constitutional change. ${ }^{59}$ Closely following critical election theory, Ackerman posits that these massive electoral shifts are what overcome the conservative effects of the constitutional separation of powers and unify the government under a single banner. ${ }^{60}$ Absent a mobilized electorate, proposals for constitutional change are redirected into the institutional and political diffusion of normal politics. ${ }^{61}$

A second and related feature of Ackerman's approach is its emphasis on big revolutions, or transformations..$^{2}$ Perhaps unsurprisingly, Ackerman has devoted most of his attention to some of the biggest political and constitutional upheavals in American history. ${ }^{63}$ The later constitutional moments identified by Ackerman $^{64}$ are comparable to the Founding, in both the unconventional nature and the substantive significance of the constitutional changes they wrought. These later moments may be limited revolutions-they transform rather than abandon the inherited constitutional order-but they are revolutions nonetheless. They remake the very foundations of the constitutional order (justifying the division of American history into distinct constitutional regimes), require decades of effort to fully realize and synthesize their effects, and appeal to the deepest aspirations and concerns of the American people.

The model of constitutional moments also emphasizes relatively sudden conflicts and shifts. ${ }^{65}$ The task of synthesizing and interpreting the constitutional changes may take decades, but the effort of making higher law is over within one or two election cycles. ${ }^{66}$ Although the tensions in the existing constitutional regime and the movement advocating reform may take years to develop, the transformation of mass opinion and dominant political alignments is sudden. In par-

59. Id. at $18-25$.

60. 1 ACKERMAN, supra note 41, at 47-51; 2 ACKERMAN, supra note 41, at 21, 24-25. On this dynamic, see WALTER DEAN BURNHAM, CRITICAL ELECTIONS AND THE MAINSPRING OF AMERICAN POLITICS 175-85 (1970) (discussing the role of critical elections as the driving force of political change in American history). Notably, theories of critical elections have emphasized political parties as the instrument of electoral responsiveness, government consolidation, and policymaking.

61. 1 ACKERMAN, supra note 41, at 269-72.

62. Id. at 58-80; 2 ACKERMAN, supra note 41, passim.

63. 1 ACKERMAN, supra note 41, at 44-67.

64. Ackerman focuses on the Reconstruction amendments and the New Deal as being comparable to the Founding in their constitutional effects. 2 ACKERMAN, supra note 41, at 1727.

65. 1 ACKERMAN, supra note 41, at 266-94.

66. Id. at $285-90$. 
ticular, Ackerman highlights the role of one institution in creating an impasse to reform that must be overcome through extraordinary means. ${ }^{67}$ Resistance to reform is natural in normal politics, but the climactic institutional impasse is crucial to sharpening the constitutional reforms being proposed and mobilizing popular support behind them. ${ }^{68}$ The "switch in time" of the resistant institution in the face of the overwhelming forces of reform effectively ratifies the constitutional change and marks the beginning of the consolidation of the new order. The climactic moments of the ratification of the Philadelphia Constitution, the impeachment of President Andrew Johnson and unorthodox ratification of the Fourteenth Amendment following the congressional elections of 1866, and the Court-packing plan and judicial reversal following the elections of 1936 are exemplars of the mechanisms of constitutional transformation.

There is a substantial amount of constitutional pushing and shoving, and innovation, that goes on outside the context of such electorally driven transformations. ${ }^{69}$ Critical elections are not the only mechanism of political change, and constitutional moments of popular mobilization are not the only mechanism of constitutional change. $^{70}$ One complication of critical election theory comes from attempting to extend the lessons of these historical political events to

67. 2 ACKERMAN, supra note 41, at 18-24.

68. Id. at $280-88$.

69. See generally Keith E. Whittington, Constitutional Construction 216-18 (1999) (describing constitutional change outside of the electoral context).

70. Ackerman himself suggests one example in the decline of the Treaty Clause as the sole procedure for entering international accords. Although Ackerman identifies 1944 as a "triggering election" on this issue, he provides no evidence that there was popular mobilization around this issue or broad and deep deliberation on this issue within the general public. BRUCE ACKerman \& DAVID Golove, Is NAFTA Constitutional? 73-96 (1995) ("[W]e do not wish to present the 1944 election as if it were a European-style referendum on this key issue."). The election simply kept the Democrats, who favored altering the procedures on international agreements, in power long enough for them to oversee the postwar reconstruction of the international order. In numerous cases, the Supreme Court has altered inherited understandings of the Constitution without prior popular mobilization initiating and authorizing such a change. The Court's conclusion that the Constitution prohibited racial segregation by the states and especially by the federal government radically changed the effective constitutional law and predated popular mobilization on this issue. See Brown v. Bd. of Educ., 347 U.S. 483, 495 (1954) (holding that "separate but equal" in the context of racial segregation is inherently unequal); Bolling v. Sharpe, 347 U.S. 497, 500 (1954) (holding that the rule in Brown applies to the federal government and the District of Columbia as well as the states). Similarly, the Court's creation of a new set of constitutional requirements governing police interrogations in the states did not reflect any popular deliberation on the issue. See Miranda v. Arizona, 384 U.S. 436, 469 (1966) (requiring police to advise arrestees of the right to remain silent). 
the present. Within political science and history, a fierce debate has raged over the continued utility of theories of critical elections. ${ }^{71}$ Some scholars doubt how well the model can explain past events and how coherent the model itself really is. ${ }^{72}$

Of greater concern for the immediate question is that many are skeptical as to whether such electoral theories are applicable to contemporary politics. There is little question that at least by the late 1960s the United States had entered a historically unusual period, which many have labeled a period of dealignment. ${ }^{73}$ In this period of persistent divided government, political parties seem less capable of organizing a coherent electoral coalition and overcoming the natural barriers of the American constitutional structure. ${ }^{74}$ Relatedly, parties seem less capable of mobilizing the broad electorate and winning loyalty from supporters. Rather than realigning in favor of a single dominant party, voters and interests have dealigned from any party. ${ }^{75}$ The New Deal coalition has broken down, but the long-awaited new majority has yet to emerge to take its place. ${ }^{76}$ In such a political context, elections may mean less and be less important than once was the

71. For an introduction to the debate, see generally THE END OF REALIGNMENT? (Byron Shafer ed., 1991) (discussing the value of the realignment theory).

72. See, e.g., Everett Carll Ladd, Like Waiting for Godot: The Uselessness of "Realignment" for Understanding Change in Contemporary American Politics, in THE END of REALIGNMENT?, supra note 71, at 24 (claiming that the realignment model has detracted attention from other important political changes); Joel H. Silbey, Beyond Realignment and Realignment Theory: American Political Eras, 1789-1989, in THE END OF REALIGNMENT?, supra note 71, at 3, 17-18 (arguing that the lessening importance of political parties makes a future realignment unlikely).

73. See Edward G. Carmines et al., Unrealized Partisanship: A Theory of Dealignment, 49 J. PoL. 376, 376 (1987) (attributing the dealignment that began in the 1960s to "unrealized partisanship"- - the failure of the maturing generation to socialize into the existing party alignment). "Dealignment" refers to the defection of some constituencies from the political parties, which is normally regarded as a transitional stage leading to a "realignment" as those constituencies join new parties. In the modern period, however, the apparent dealignment has been fairly enduring as voters remain "independent" rather than simply switching party allegiances.

74. See Lloyd N. Cutler, Some Reflections About Divided Government, 18 PRESIDENTIAL STUD. Q. 485, 486-490 (1988) (analyzing party decomposition as a cause of gridlock); Lloyd N. Cutler, To Form a Government, 59 FOREIGN AFF. 126, 136 (1980) (analyzing structural reasons for a political "stalemate").

75. Morris Fiorina, Divided GOVERnMENT 10-14, 60-85 (1992); MARTIN P. Wattenberg, The Decline of American Political Parties, 1952-1994, at 132-67 (1996).

76. Compare Kevin P. Phillips, The EMERging RePUblican Majority 461-474 (1969) (forecasting Republican realignment), with BYRON E. SHAFER \& WiLliam J.M. ClAGGETT, THE TwO MAJORITIES 168-92 (1995) (describing the possibility of a split electorate), and Paul Starr, An Emerging Democratic Majority, in THE NEW MAJORITY 224-31 (Stanley B. Greenberg \& Theda Skocpol eds., 1997) (forecasting the opportunity for a progressive realignment). 
case. ${ }^{77}$ Under such circumstances, we should not expect to see another critical election.

If this account of contemporary politics is true, then two different implications for constitutional change might follow. ${ }^{78}$ In keeping with Ackerman's model, it is possible that history has stopped. The collapse of the partisan preconditions for transformative elections may simply mean that constitutional changes will not occur. The conservative constitutional structure will continue to frustrate reformers until such a time that they can once again mobilize the mass electorate. Ackerman generally has not emphasized the partisan dimensions of his historical narrative of American constitutional development and thus has obscured both the mechanisms that have historically made such changes possible and the potentially pessimistic ending to his generally optimistic story of dualist democracy. His somewhat brief and ad hoc argument about the failure of the Reagan revolution as a constitutional moment ${ }^{79}$ may conceal a deeper truth about the modern political system, that conventional constitutional moments can no longer occur.

A second possible implication is more likely-that the theory is incomplete, and that constitutional change will continue to occur by other means. The Court's federalism offensive suggests that this must be the case. An emphasis on critical elections as a solution to the empirical and normative puzzles of constitutional change may hide alternative paths that constitutional reform has taken or may take. Such changes arguably may not be as fundamental, as enduring, or as legitimate as the types of revolutionary transformations achieved through constitutional moments, but they may be real and important nonetheless.

Constitutional changes may have popular support, and yet be neither initiated nor ratified by any critical election. Changes in popular opinion and political inclination may occur gradually over time rather than in a single climactic moment. Change may occur on

77. Benjamin Ginsberg \& Martin Shefter, Politics by Other Means 1-15, 37-75 (1990).

78. It should be noted that not all aspects of this account are universally accepted as true. Notably, Walter Dean Burnham, the leading proponent of realignment theory, has argued that "the right-wing revolution was not so much defeated [in the 1980s] as postponed" until the congressional election of 1994 and, perhaps, the presidential election of 2000. Walter Dean Burnham, Constitutional Moments and Punctuated Equilibria: A Political Scientist Confronts Bruce Ackerman's We the People, 108 YALE L.J. 2237, 2273 (1999).

79. 2 ACKERMAN, supra note 41, at 390-400. 
an issue-by-issue basis without resulting in a general realignment of the political parties, which are capable of accommodating movement on a wide variety of issues, thereby limiting the partisan and policy consequences of such shifts. Racial issues seemed to have followed this pattern. Prior to the 1960s, race did not map neatly along partisan or ideological divisions. The firm inclusion of the southern Democrats in the New Deal coalition prevented the Democratic Party from adopting a single coherent position on race, which likewise discouraged the Republican Party from making race a central issue. Lyndon Johnson's embrace of racial civil rights, countered by Barry Goldwater's embrace of racial conservatism, began a process of polarization that required years to develop fully. Over time, racial liberalism was integrated into political liberalism and the Democratic Party, as racial conservatism was integrated into political conservatism and the Republican Party. Such cases suggest that "gradual transformations in the party system are probably more typical [than abrupt transformations], occur more frequently, and account for the largest proportion of political change." ${ }^{, 0}$

Ackerman's model also may be incomplete in that it does not account for situations in which no institution or actor can create an impasse that would necessitate extraordinary action by reformers, or, to the extent that such obstructions and struggles occur, they must take place outside of the institutional context of the national government. Government officials may respond to events that they witness in the social sphere without waiting for the electoral and institutional struggle for reform to develop. Constitutional change may emerge from a number of decisions, but not be itself an object of conscious choice. ${ }^{81}$ Such political dynamics may avoid the kind of self-conscious constitutional deliberation and mobilization that Ackerman observes in his cases. Effective constitutional meaning may change through general agreement, incremental adjustment, and bargaining, circumventing the revolutionary conflict-and-resolution that characterized the $1860 \mathrm{~s}$ and 1930s. Ackerman's impasses and unconventional amendment efforts may be particularly avoidable when the issues involved are limited, less intense, and less politically salient, and thus unlikely to pro-

80. EDWARD G. CARMines \& JAMES A. Stimson, IsSUE EVOlution 157 (1989); see also KeITH T. PoOle \& Howard Rosenthal, CONGRess 109-14 (1997) (describing how new issues are incorporated into the existing partisan structure).

81. See Keith E. Whittington, Dismantling the Modern State? The Changing Structural Foundations of Federalism, 25 HAST. CONST. L.Q. 483, 486-88 (1998) (describing twentieth century changes in federalism as a result of the interaction of several political trends). 
voke any significant political actor into becoming as intransigent as President Johnson or the Lochner-era Court. Most constitutional issues may be of interest only to a few and may not be of sufficient salience to support a broad-based political movement. ${ }^{82}$ Such impasses also may be less likely to develop when the substantive dispute involves the reduction, rather than the expansion, of government power, thus minimizing the likelihood of judicial review. ${ }^{83}$ Although the Court's recent federalism decisions evoke memories of the Lochner-era Court, the Rehnquist Court thus far has avoided creating the kind of institutional impasse the early-twentieth-century Court created.

Constitutional change may result from the actions of political elites without any substantial participation by the masses. In Ackerman's own case studies, constitutional innovation largely is initiated by elites (though perhaps drawing on reform movements with deeper roots). ${ }^{84}$ High-level government officials are driven to appeal to the people broadly only when faced with the obstruction of other government officials who cannot be overcome by other means. ${ }^{85}$ It is the strength of the resistance to the constitutional change that forces reformers to mobilize the people on their own behalf. Popular mobilization is a tactical decision within a political struggle over constitutional forms, and such decisions are necessarily contingent on the inadequacy of other means to overcome the obstructionist officials.

The Supreme Court particularly may be unlikely to seek popular participation in pushing forward constitutional change. It is instructive that elected officials - not appointed judges - turned to the people for reinforcement in Ackerman's cases of Reconstruction and the New Deal. ${ }^{86}$ It is perhaps unsurprising that elected officials would seek support from their own electorates and vaunt their mandates when faced with political opposition. By contrast, the Supreme Court

82. Karl N. Llewellyn, The Constitution as an Institution, 34 COLUM. L. REV. 1, 19-26 (1934); Charlotte Twight, Constitutional Renegotiation: Impediments to Consensual Revision, 3 CONST. POL. ECON. 89, 91-101 (1992).

83. See Mark A. Graber, The Jacksonian Origins of Chase Court Activism, 25 J. SuP. CT. HIST. 17, 27 (2000) ("Fundamental questions of constitutional power could not be litigated before the Supreme Court as long as the party of more narrow constitutional construction was victorious in the elected branches of government.”); Kent Greenawalt, Dualism and Its Status, 104 ETHICS 480, 497 (1994) ("No constitutional law change was critical to accomplishment of Reagan's major objectives ....").

84. 2 ACKERMAN, supra note 41, at 160-85, 312-44.

85. Id. at $186-88,306-11$.

86. Id. at 18-20, 23-25. 
is institutionally ill equipped to appeal over the heads of elected representatives to the people themselves. If the Court were to initiate constitutional change, it would be unlikely to win support through a critical election. Popular acquiescence to its decisions is about all the Court can expect to attain. But acquiescence may be enough to effectuate change. Ackerman has not yet provided a detailed accounting of the rise of either the Lochner-era Court or the Warren Court, though he places both in the role of interpreting and preserving the unconventional constitutional amendments put in place a generation earlier. ${ }^{87}$ It could be argued plausibly, however, that both Courts were activist in the sense of being constitutional innovators. ${ }^{88}$ As such, these Courts may have led, rather than followed, other government officials and the electorate toward important constitutional changes. In doing so, both Courts may have encountered resistance and provoked public argument about their actions, but neither Court sought or won popular ratification of their actions in the sense that Ackerman envisions. The majority on each of those Courts took advantage of the political environment to advance a distinct constitutional agenda. The Rehnquist Court is doing the same.

\section{ThE REHNQUist COURT'S VELVET REVOLUTION}

If there has been a revolution in the constitutional law of federalism over the past decade, it has not been the kind of tumultuous revolution described by Bruce Ackerman. The Rehnquist Court has not stormed the barricades of the centralized state while rallying the masses to its devolutionary banner. At the same time, the federalism offensive is without question a political event. Laying aside the motives of the majority of the Justices on the Court, the Court's actions are rife with political consequences and concerns. A revolution in the law requires more than an intellectual awakening. ${ }^{89}$ It requires concerted effort, careful strategy, and good luck. Ackerman and the new institutionalists have alerted scholars to the political obstacles to con-

87. 1 ACKERMAN, supra note 41 , at 131-59.

88. See, e.g., Lucas A. Powe, The Warren Court And American Politics 485-501 (2000) (discussing the areas of constitutional law that the Warren Court addressed and placing the Court in its contemporary political context); Burnham, supra note 78, at 2267-70 (noting that the Lochner-era Court and the Warren Court built on prior constitutional changes by expanding constitutional law far beyond what was anticipated when the original change was made).

89. See Robert Justin Lipkin, Constitutional ReVolutions 118-53 (2000) (treating constitutional revolutions as a matter of judicial deliberation). 
stitutional change and the difficulty with which reformers negotiate them. ${ }^{90}$ The Court has deduced that the social and political context is conducive to constitutional reform on federalism, the Justices are willing to exploit those opportunities, and the Court has been politically astute in advancing its agenda without triggering serious opposition.

The Court's recent actions were hardly inevitable. Undoubtedly, these federalism decisions seem particularly precarious, given that they generally depended on exceedingly thin one-vote majorities, and that the future of those decisions easily could have been affected by the national elections of 2000. A Democratic presidential victory would have made the majority, and probably those recent precedents, exceedingly vulnerable to changes of personnel on the Court. Nonetheless, the fragility of the Court's federalism majority should not obscure the fact that the decisions also grew out of a particular social and political context that made them more likely and more sustainable. This larger context created political openings the Court chose to exploit, and it provided the intellectual foundations to motivate and legitimate the actions the Court has taken.

By the end of the twentieth century, the time was ripe for a revival of judicial interest in the constitutional restrictions on national power imposed by the federal structure. Serious judicial interest in federalism was nearly inconceivable in the decades after the Court's 1937 retreat from the battle over the New Deal, in which the Court's federalism jurisprudence suffered increasing strain leading up to an eventual retreat. ${ }^{91}$ The social and political conditions favoring centralization had begun to erode by 1976, when the Court tested the waters of federalism again, ${ }^{92}$ and they were in full decline by the early 1990s, when the Court began its current, more sustained questioning of the post-New Deal federalism jurisprudence. ${ }^{93}$

Those changing conditions need only be outlined here. Social and economic changes, and the political interpretation of those

\footnotetext{
90. 1 ACKERMAN, supra note 41, at 254-94; WhitTington, supra note 69, at 214-23.

91. On judicial developments during this period, see CusHMAN, supra note 9, at 141-225 (describing the events leading to the New Deal crisis).

92. See Nat'l League of Cities v. Usery, 426 U.S. 833, 845-52 (1976) (holding that Congress lacks the authority to interfere in traditional state governmental functions).

93. See New York v. United States, 505 U.S. 144, 159-66 (1992) (holding that Congress may not commandeer state legislative processes); Gregory v. Ashcroft, 501 U.S. 452, 457-64 (1991) (holding that state authority over state government officials is essential to the federal structure).
} 
changes, in the early and middle twentieth century drove the centralization of government power. It was not until the very end of the nineteenth century that the United States developed a truly national economy and began to develop a national culture. Intimately connected to those economic and social transformations was the rise of an administrative ethos of management and control of social forces. ${ }^{94}$ The new corporate managers had no use for destabilizing economic competition or inefficient subnational political diversity. The same mindset infused government during the Progressive Era and encouraged a turn to centralized, bureaucratic expertise in formulating and implementing government policy. The economic and social dislocations caused by the developing corporate economy also encouraged positive state action to address them. ${ }^{95}$ Centralization was recognized to be complementary to the successful use of the regulatory and redistributive functions of government, especially in this new economic context. The states proved incapable of successfully addressing the political demands of the early twentieth century. Worse, the states were perceived as part of the problem for many of the moral reform movements of the twentieth century, including most notably the racial civil rights movement. ${ }^{96}$ Neither the conceptual tools nor the normative pieties of the Court's federalism doctrine traveled well in this new environment. Federalism could be seen as an outmoded or even tragic element of the American constitutional scheme and appropriately subject to political reconsideration and adjustment.

In recent decades, these economic and social conditions have changed. The administrative ethos and its promise of policymaking free of politics and better living through rational planning are met with increasing skepticism and a greater appreciation for decentralized decisionmaking. ${ }^{97}$ The centralized positive state that was thought necessary to deal with the Great Depression and the Second World War holds fewer charms, given the new array of political concerns

94. See Whittington, supra note 81 , at 490-93 (discussing the administrative ethic and the progressive movement).

95. See id. at 493-500 (discussing the centralization of government power during the first half of the twentieth century).

96. See id. at 500-03 (discussing the public morality of the Progressive Era). Notably, the national government itself encouraged the view that federalism was responsible for civil rights concerns at mid-century. See MARY L. DUDZIAK, COLD WAR CIVIL RIGHTS 148, 182-83, 215, 229-30, 241 (2000) (discussing the diplomatic strategy of blaming federalism for racial injustice).

97. See Whittington, supra note 81 , at 515-16 (describing the declining faith in administrative ethos). 
and the decades of experience with the policy successes and failures of the national government. ${ }^{98}$ Although the night watchman state concerned only with keeping the peace-is not about to become the new political ideal, the national government has fewer comparative advantages in addressing contemporary political issues, and centralization is less essential to national goals. ${ }^{100}$ National politicians can be expected to continue trying to win electoral favor by responding to popular dissatisfactions, but their contributions on salient issues ranging from education to crime control, from environmentalism to economic development, are more evidently marginal and supplementary than they were to the central political issues of earlier periods. The states also have benefited from earlier reform efforts and an altered public consciousness. ${ }^{101}$ The states are more professional, more capable, and less venal than they once were. ${ }^{102}$ They are also less evidently out-of-step with mainstream national values, and those values are themselves less certain and single-minded than during such reformist periods as the 1960 s. ${ }^{103}$ Such foundational changes have mani-

98. See id. at 503-15 (hypothesizing about a shift toward a more decentralized state after the 1960s).

99. Robert NOZICK, ANARCHY, STATE, AND Utopia 26 (1974) ("[T]he night-watchman state of classical liberal theory [is] limited to the functions of protecting all its citizens against violence, theft, and fraud, and to the enforcement of contracts, and so on ....").

100. The primary comparative advantage of the national government is in regulatory and redistributive policy areas, where affected actors might otherwise flee political jurisdictions to escape government-imposed costs. The increased capacity of people and businesses to escape across even international borders and the declining importance of these policy areas on the American political agenda reduces the comparative advantage of the national government vis-àvis the states and localities as a policy provider. Of course, the national government also has primary responsibility for national defense, and the centralization of political power tends to accompany wartime mobilization. The more enduring and comprehensive the mobilization, the greater the centralization is likely to be, and it is likely to cross a wider range of policy areas. It remains uncertain how extensive the national government's domestic mobilization behind the new "war on terrorism" will be, but it seems unlikely that it will have significant consequences for the Court's activities in such areas as the Commerce Clause, state sovereign immunity, or the scope of Section 5 of the Fourteenth Amendment.

101. See Whittington, supra note 81, at 520-22 (suggesting that the states have benefited from, and changed due to, both internal and external forces).

102. See DAVID B. WALKer, The RebirTH OF Federalism 249-83 (1995) (embracing the concept of a resurgent role for the states); Mavis Mann Reeves, The States as Polities: Reformed, Reinvigorated, Resourceful, 509 AnNALS AM. ACAD. POL. \& SOC. SCI. 83, 84 (1990) (noting that " $[\mathrm{t}] \mathrm{he}$ role and condition of the states are crucial in any assessment of intergovernmental relations"). See generally ANN O'M. BOWMAN \& RiCHARD C. KEARNEY, THE RESURGENCE OF THE STATES 1-104, 187-256 (1986) (enumerating several reasons for state revitalization, including reform in both the executive branch and in state governments).

103. See Whittington, supra note 81, at 516-22 (emphasizing the notion that a resurgence of state power "requires the moral recovery of the states"). 
fested themselves in, among other things, a striking deterioration in the citizenry's support for and trust in the national government relative to state and local governments. ${ }^{104}$

It is possible that the Justices have considered such features of modern American life and have developed a policy preference for devolution. They may act directly on that policy preference ${ }^{105}$ or convince themselves by a process such as that described by Professor Schroeder that their preferences are consistent with constitutional requirements. ${ }^{106}$ The economic circumstances of the 1930s put immediate intellectual and practical pressure on inherited ideas and doctrines about federalism. There was no similar tension between circumstance and doctrine in the 1990s. It would not be implausible to imagine that if the Constitution was "besieged" by the circumstances of the early twentieth century, and New Deal Justices took steps to accommodate those circumstances, ${ }^{107}$ then the circumstances of the late twentieth century simply created a space to reevaluate that accommodation. The old, exiled Constitution, as understood by traditional legal reasoning, simply could be reasserting itself in the judicial mind now that the siege has ended. Given the divergent reactions of many to these changing conditions (many still trust the national government), the divergent legal implications of such a transformation (those who favor policies of decentralization need not, as a legal matter, favor constitutionally enforced decentralization), and the fragmented constitutional discourse (was the old Constitution "exiled," "amended," or "corrected" in the 1930s?), it is not surprising that only some judges would join the federalism offensive. At the same time, a larger social environment that at least renders problematic the normative and empirical assumptions of the New Deal jurisprudence could be expected to produce at least a few judges who would come to doubt the constitutional fidelity of that jurisprudence.

\footnotetext{
104. See Schroeder, supra note 15, at 352-56 (describing a judicial decisionmaking model based on the theory of motivated reasoning).

105. It might be noted that this account of twentieth-century tendencies does not have a very specific attitudinal implication. It could support a general principle of decentralization or more specific preferences about which policies should be decentralized and which should not.

106. I believe the attitudinalists would have no difficulty embracing Professor Schroeder's description of the judicial cognitive process. See Schroeder, supra note 15, at 352-56 (modeling judicial decisionmaking processes on the cognitive theory of motivated reasoning). The external model would work just the same with or without the psychological account.

107. See GiLlman, supra note 9, at 147-93 (characterizing the post-Lochner era as a battle between a progressive social movement and its conservative opponents).
} 
The changed circumstances of the late twentieth century are important for the Court in at least two ways. First, it creates the political opportunity for the Court to pare back the centralizing excesses of the post-New Deal constitutional law. Professor Schroeder argues that from the perspective of the individual citizen or elected official "the perceived costs of not reposing trust in the federal government has been declining, making it easier to allocate authority to state and local governments." ${ }^{108}$ This dynamic also makes pro-decentralization judicial decisions less costly to other political officials. Prodecentralization judicial decisions are less painful to other political actors in the 1990s than they were in the 1930s, and, as a consequence, important political actors can be expected to be more tolerant of such decisions and less willing to expend political capital to challenge them. The Court's effective range of politically acceptable action on federalism has widened as the drive for centralization on the part of other powerful political actors has lessened. The odds of encountering an institutional impasse to the Court's new federalism offensive has been reduced, and, thus, it is now easier and safer for the Court to take this course than it would have been even two or three decades ago.

Second, the intellectual context of the Rehnquist Court era helps legitimate the Court's federalism offensive. All political actors need some principled rationale beyond their personal preferences in order to effectively exercise political power. ${ }^{109}$ The Court may feel this need particularly strongly. As Alexander Hamilton famously observed, the judiciary has the advantage of neither the sword nor the popular will, relying only on the persuasiveness of its judgment. ${ }^{110}$ Moreover, the forms of legitimation available to the Court are particular. ${ }^{111} \mathrm{Al}-$ though contemporary theory and politics can support a wide range of conflicting constitutional interpretations, there remain limits on what the Court plausibly can claim that the Constitution means before it raises substantial questions about its actions. For example, despite the hard work of numerous revisionist scholars, the Supreme Court's

108. Schroeder, supra note 15 , at 342 .

109. See MARTIN SHAPIRO, COURTS 1-64 (1981) (listing the preservation of their perceived neutrality as a central problem that courts face).

110. The Federalist No. 78, at 465 (Alexander Hamilton) (Clinton Rossiter ed., 1961).

111. See Philip Bobbitt, Constitutional InTERPRetation 1-42 (1991) (outlining six modalities of constitutional debate that help maintain the legitimacy of judicial review). 
Lochner v. New York ${ }^{112}$ opinion continues to ring false to modern ears. As Oliver Wendell Holmes charged in his dissent at the time, the Court's arguments in Lochner tend to strain credulity and invite concerns that the Justices merely were legislating their policy preferences. ${ }^{113}$ A modern Court could not easily attempt to revive that reasoning and doctrine.

Dual federalism is not as notorious as substantive due process, but as long as the view was common that "if in the United States one disapproves of racism, one should disapprove of federalism," the Court could hardly place the protection of federalism at the center of its jurisprudence, and would be unlikely to want to do so. ${ }^{114}$ The reversal of fortunes of the national and state governments in terms of public trust during the last three decades of the twentieth century ${ }^{115}$ created a friendlier normative environment for the Court's revival of interest in federalism. Striking down congressional statutes in favor of state and local authority became more acceptable when Congress was perceived as "the public enemy." Court has benefited from the efforts of the conservative legal intellectual movement to build scholarly respectability for a more restrictive federalism jurisprudence. ${ }^{117}$ The Supreme Court itself helped revive

112. 198 U.S. 45 (1905). For an overview of the revisionist history of Lochner, see generally

Gary D. Rowe, Lochner Revisionism Revisited, 24 L. \& SOC. INQUIRY 221 (1999).

113. Lochner, 198 U.S. at 75-76 (Holmes, J., dissenting).

114. William H. RiKER, FEDERALISM 155 (1964).

115. See Schroeder, supra note 15, at 346-51 (observing that public perceptions of elected officials, among other factors, contributed to the severe decline in public trust in the federal government); see also Pew Research Center, Deconstructing Distrust: How Americans View Government, tbls.1, 2, at http://www.people-press.org/trusttab.htm (last visited Aug. 21, 2001) (on file with the Duke Law Journal) (tracking the decline in trust in the federal government); NBC News/Wall Street Journal Poll of December 7, 2000, Roper Center, at http://web. lexis-nexis.com/universe (last visited Aug. 23, 2001) (accession number 0376554) (on file with the Duke Law Journal) (finding that only 25 percent of those polled have the "most trust" in federal government, compared to 29 and 36 percent for state and local governments).

116. See John Hibbing \& Elizabeth Theiss-Morse, Congress As Public ENemy 3136, 158-62 (1995) (describing the lack of public support for Congress as an institution).

117. See, e.g., Raoul Berger, Federalism: The Founders' Design 77-176 (1987) (probing the original intent regarding federalism); Charles J. Cooper, The Demise of Federalism, 20 URB. LAW. 239, 245-80 (1988) (observing the decline of federalism as a constitutional principle); Richard A. Epstein, The Proper Scope of the Commerce Power, 73 VA. L. REV. 1387, 1443-54 (1987) (insisting that "the expansive construction of the [commerce] clause accepted by the New Deal Supreme Court is wrong"); Robert F. Nagel, Federalism as a Fundamental Value: National League of Cities in Perspective, 1981 SUP. CT. REV. 81, 97-109 (emphasizing the importance of National League of Cities in recalling basic "constitutional principles"); see also CHARLES FRIED, ORDER AND LAW 186-88 (1991) (discussing concerns for federalism in the Reagan administration); Jonathan Mahler, The Federalist Capers, 8 LINGUA FrANCA 38, 39-41 
interest in the subject with its 1976 National League of Cities v. Usery opinion. ${ }^{118}$ Some commentators have suggested that the opinion primarily was intended to be educative rather than regulative, simply intended to remind the nation of federalism principles without signaling any sustained effort to enforce them. ${ }^{119}$ Although this interpretation probably gives greater intellectual coherence to the Court's actions than is warranted, it may well be true that the opinion served such a function. Consistent with conservative political attacks on the "big government" in Washington and the rise of originalist theories of constitutional interpretation, some legal academics and lawyers began to reconsider the doctrinal burial of federalism. ${ }^{120}$ In doing so, they helped lend legitimacy to the Court's later actions.

Ultimately, a willing Court must exploit such opportunities if they are to be realized in constitutional law. The Rehnquist Court has proved willing. The federalism offensive has required a steady stream of appropriate cases, at least five fairly united Justices, and at least one judicial entrepreneur interested in pressing this particular constitutional agenda. The ready availability of appropriate cases is an obvious prerequisite for significant judicial alteration of constitutional law, but one that cannot be assumed. ${ }^{121}$ The judiciary is a reactive institution that must wait for disputes and issues to be brought to it (though judges can signal their willingness to hear certain kinds of cases). ${ }^{122}$ Constitutional litigation is a difficult and expensive process, however, and especially when an issue is not very socially or politically salient, the appropriate cases may not work their way up the judicial hierarchy to the Court. The federalism offensive has benefited from the participation of state governments, which are powerful potential litigants with an interest in this issue, as well as a number of

(1998) (describing the rise of the Federalist Society). See generally Symposium on Federalism, 6 HARV. J.L. \& PUB. POL'Y 1 (1982) (examining the importance of federalism in the eyes of conservative scholars and policymakers).

118. 426 U.S. 833, 840-52 (1976).

119. Philip Bobbitt, Constitutional Fate 190-95 (1982); Robert F. NAgel, Constitutional Cultures 79-82 (1989).

120. See supra note 117.

121. See Charles R. Epp, The Rights Revolution 11-70 (1998) (examining the importance of a litigation "support structure" to a judicial "rights revolution"); see also MARK V. Tushnet, THE NAACP's LegAl StRATEgy AgAinst SEgREgATEd EduCATION, 1925-1950, at 70-166 (1987) (detailing the litigation campaign to overturn racial segregation in public education).

122. Such judicial signals are sometimes fairly explicit, as when the Justices offer suggestions as to how they might rule in future cases. At other times, signals to potential litigants are implicit in the recent pattern of decisions, both on certiorari and on the merits. 
conservative public interest groups who are willing to develop federalism-based claims. ${ }^{123}$

The votes supporting the federalism offensive came through replacement rather than through conversion. New York v. United States $^{124}$ in 1992 may be taken as the beginning of the current federalism revival. ${ }^{125}$ That case stands out from the subsequent federalism cases in that all nine Justices joined at least part of the majority opinion, whereas the subsequent cases have been decided by identical 5-4 votes. ${ }^{126}$ The renewed interest in federalism on the Court is clearly part of the legacy of President Ronald Reagan. Of the five Justices in the federalism majorities-Chief Justice Rehnquist, Justices O'Connor, Scalia, Kennedy and Thomas-three were Reagan appointees, and Reagan elevated the Chief Justice to his current position. The remaining Justice, Justice Thomas, was appointed by George Bush and clearly reflected Reagan-era legal conservatism.

Federalism was not a priority of the Nixon administration. ${ }^{127}$ Nixon always had an uneasy relationship with the "new right" and its ideological concerns. ${ }^{128}$ Although Nixon's administration did push a federalism initiative, it was largely pragmatic and did not question the basic role of the national government in the post-New Deal order. ${ }^{129}$ By contrast, Reagan's interest in federalism was closely related to his interest in limited government, and, as a consequence, it had greater constitutional implications and broader ideological significance. ${ }^{130}$

123. See Paul Chen, The Supreme Court's Federalism Jurisprudence and the Rise of the New Right 2-5 (Mar. 2001) (unpublished manuscript, on file with the Duke Law Journal) (describing the rising importance of conservative public interest groups as a necessary institutional shift to support the Supreme Court's recent decisions).

124. 505 U.S. 144 (1992).

125. But see Gregory v. Ashcroft, 501 U.S. 452, 457-64 (1991) (limiting application of the Age Discrimination in Employment Act with regard to state judges, thereby upholding statemandated retirement for judges, one year before the decision in New York).

126. A large number of the Court's recent federalism cases have been decided by an identical five-Justice majority comprised by Chief Justice Rehnquist and Justices O'Connor, Kennedy, Scalia, and Thomas. See Bd. of Trs. of the Univ. of Ala. v. Garrett, 531 U.S. 356 (2001); Solid Waste Agency v. United States Army Corps of Eng'rs, 531 U.S. 159 (2001); United States v. Morrison, 529 U.S. 598 (2000); Kimel v. Fla. Bd. of Regents, 528 U.S. 62 (2000); Alden v. Maine, 527 U.S. 706 (1999); Coll. Sav. Bank v. Fla. Prepaid Postsecondary Educ. Expense Bd., 527 U.S. 666 (1999); Printz v. United States, 521 U.S. 898 (1997); Seminole Tribe v. Florida, 517 U.S. 44 (1996); United States v. Lopez, 514 U.S. 549 (1995).

127. Melvin SMall, The PresidenCy OF Richard NiXon 194-95 (1999).

128. JOAN HOFF, NIXON RECONSIDERED 78-79 (1994); SMALL, supra note 127, at 153-55.

129. HoFF, supra note 128 , at 65-73.

130. See Demetrios Caraley, Changing Conceptions of Federalism, 101 POL. SCI. Q. 289, 292-96, 304-06 (1986) (describing Reagan's federalism initiatives as part of a broader conserva- 
These presidents' differing visions affected their appointments to the Court. Nixon's goals in choosing Justices were as much political as ideological, and even his ideological concern with selecting "strict constructionists" for the Court was oriented toward the themes of his "law and order" campaign. ${ }^{131}$ By contrast, Reagan's appointment strategy was tightly focused on jurisprudential considerations, considerations including support for "deference to states in their spheres" and "recognition that the federal government is one of enumerated powers." ${ }^{132}$ To the extent that federalism commitments lost out to competing values and interests in the policymaking of the Reagan administration, the appointment of judges supportive of federalism was an important strategy for making conservative commitments to decentralization credible and effective. ${ }^{133}$

The Court's jurisprudence reflected these different presidential concerns. Although more conservative than its predecessor on some issues, most notably criminal justice, the Burger Court, with its four Nixon appointees, was no more sympathetic to states and localities on federalism issues than its predecessors. ${ }^{134}$ Then-Associate Justice William Rehnquist was, of course, the exception to this pattern. Rehnquist received minimal consideration before his nomination by the Nixon administration, but the Reagan administration enthusiastically embraced him as the exemplar of a Reagan Justice, ${ }^{135}$ in part because of his National League of Cities opinion. On the Burger Court, only the Reagan-appointed Justice O'Connor voted with Rehnquist

tive agenda); see also Richard P. Nathan, Review of The New Federalism, 104 POL. SCI. Q. 342, 342-43 (1989) (reviewing Timothy CONLAN, NeW Federalism, InTERgOvernmental REFORM FROM NIXON TO REAGAN (1989)) (distinguishing the federalism initiatives of Nixon and Reagan).

131. See DAVID Alistair YAlof, Pursuit OF Justices 97-125 (1999) (examining Nixon's nominations to the Supreme Court through the lens of his political and policy objectives). In announcing his nomination of Lewis Powell and William Rehnquist to the Court, Nixon chose to emphasize his desire to "strengthen the hand of the peace forces" against the "criminal forces" as central to his "judicial philosophy." Richard Nixon, Address to the Nation Announcing Intention to Nominate Lewis F. Powell, Jr., and William H. Rehnquist to Be Associate Justices of the Supreme Court of the United States (Oct. 21, 1971), in PUBLIC PAPERS OF THE PRESIDENTS OF THE UNITED STATES: RiCHARD NiXON, 1971, at 1055 (1972).

132. YALOF, supra note 131, at 143-44.

133. For an assessment of Reagan-era policy choices, see Timothy J. Conlan, Federalism and Competing Values in the Reagan Administration, 16 Publius 29, 44-46 (1986).

134. With only three Reagan appointments, the early Rehnquist Court was little different. Richard C. Kearney \& Reginald S. Sheehan, Supreme Court Decision Making: The Impact of Court Composition on State and Local Government Litigation, 54 J. POL. 1008, 1022-23 (1992).

135. DAVID G. SAVAge, TURNING RIGHT 6-19 (1992); YALOF, supra note 131, at 124, 14950,153 . 
more than 70 percent of the time on cases involving federalism issues. ${ }^{136}$ The Nixon-appointed and conservative Chief Justice Burger was no more likely to agree with Rehnquist on these issues than was the arch-liberal Justice Brennan. ${ }^{137}$ Federalism was the one issue area in which Burger did not walk in near lockstep with Rehnquist. ${ }^{138}$ Reagan and Bush appointed not just conservative Justices, but Justices who were much more conservative on federalism than their predecessors. A comparison of sitting Justices with their predecessors reveals a dramatic increase in their agreement with Chief Justice Rehnquist. Only Justice Souter was effectively the same as his predecessor on constitutional federalism cases.

\section{AGREEMENT WITH REHNQUIST ON FEDERALISM ISSUES INVOLVING NATIONAL SUPREMACY ${ }^{139}$}

\begin{tabular}{lcllc}
\hline $\begin{array}{c}\text { Departing } \\
\text { Justice }\end{array}$ & $\begin{array}{c}\text { Agreement } \\
\text { with } \\
\text { Rehnquist }\end{array}$ & $\begin{array}{c}\text { Reagan/ } \\
\text { Bush } \\
\text { Appointee }\end{array}$ & $\begin{array}{c}\text { Agreement } \\
\text { with } \\
\text { Rehnquist }\end{array}$ & Change \\
\hline Stewart & $55 \%(38)$ & O'Connor & $89 \%(96)$ & +34 \\
Burger & $50 \%(58)$ & Scalia & $96 \%(77)$ & +46 \\
Powell & $52 \%(61)$ & Kennedy & $93 \%(65)$ & +41 \\
Brennan & $51 \%(83)$ & Souter & $50 \%(51)$ & -1 \\
Marshall & $50 \%(82)$ & Thomas & $93 \%(50)$ & +43 \\
\hline
\end{tabular}

136. LeE EPSTEIN ET AL., THE SUPREME COURT COMPENDIUM 527-28 (1996).

137. Id. at 527. The Burger-Rehnquist agreement rate in federalism cases was 61.7 percent, while the Brennan-Rehnquist rate for the same period was 60.3 percent. Id.

138. Id. at 527-28. Overall, Burger's agreement with Rehnquist was 87 percent, exceeded during the period only by O'Connor's 88 percent. Id.

139. Harold J. Spaeth, United States Supreme Court Judicial Database, 1953-2000 Terms, at http://www.ssc.msu.edu/ pls/pljp/sctdata1.html (last visited Oct. 10, 2000) (on file with the Duke Law Journal). Figures are the percentage of cases in which each of the Justices voted in favor of the same party as Chief Justice Rehnquist. Figures in parentheses are the total number of cases in which the Justice and Chief Justice Rehnquist both participated. The agreement scores of the Justices were compiled using the cross-tabulate function of the SPSS statistical software, crossreferencing the votes of each of the listed Justices with the votes of Chief Justice Rehnquist on all cases with issues codes 930-49 (constitutional federalism cases involving national supremacy and "miscellaneous federalism cases"). The table was compiled using voting information through the completion of the Court's 1999 Term. 
It is particularly notable that on federalism, O'Connor and Kennedy are fairly firmly within the conservative bloc. ${ }^{140}$ In many of the Rehnquist Court's constitutional cases, those two Justices have provided the constraining force against change. ${ }^{141}$ The more conservative jurisprudential inclinations of Chief Justice Rehnquist and Justices Scalia and Thomas are reined in by the moderating inclinations of Justices O'Connor and Kennedy, often joined by Justice Souter. By contrast, the conservative wing of the Court is relatively united on federalism, and therefore has been able to sustain a longer, broader, and more substantial reconsideration of the constitutional relations between the national government and the states than in other areas, where the possibility of defection and the necessity of compromise are greater. Justice O'Connor, for example, wrote the majority opinions in New York v. United States ${ }^{142}$ and Gregory v. Ashcroft ${ }^{143}$ that launched the federalism offensive. She signaled her willingness to go even further than Chief Justice Rehnquist in restraining the national government's influence over the states in her dissent in South Dakota v. Dole. ${ }^{144}$ Justice Kennedy still may be a limiting force on the majority, however. Despite writing important majority opinions in City of Boerne v. Flores ${ }^{145}$ and Idaho v. Coeur d'Alene Tribe, ${ }^{146}$ Kennedy pointedly swung against the states in U.S. Term Limits, Inc. v. Thornton. ${ }^{147}$

This Court is also notable for having a number of Justices who take a particular interest in federalism. Significant change is difficult to accomplish within any institution. One of the difficulties in orchestrating change is the sheer quantity of issues that most political actors must face. The Justices, like other government officials, are presented

\footnotetext{
140. Jeffrey Rosen, A Majority of One, N.Y. TIMES, June 3, 2001, § 6, at 32.

141. See Charles Lane, Laying Down the Law, Justices Ruled with Confidence, From Bush v. Gore Onward, Activism Marked Past Term, WASH. PosT, July 1, 2001, at A6 (noting that Justices Kennedy and O'Connor often are the swing votes for the conservative bloc).

142. 505 U.S. 144 (1992).

143. 501 U.S. 452 (1991).

144. 483 U.S. 203, 212 (1987) (O'Connor, J., dissenting) (narrowly construing the permissible conditions that the federal government may impose on states in accepting grants-in-aid).

145. 521 U.S. 507 (1997).

146. 521 U.S. 261 (1997).

147. 514 U.S. 779, 838 (1995) (Kennedy, J., concurring) (“[T]here exists a federal right of citizenship, a relationship between the people of the Nation and their National Government, with which the States may not interfere."); see also Earl M. Maltz, Justice Kennedy's Vision of Federalism, 31 RUTGERS L.J. 761, 764-67 (2000) (noting that Justice Kennedy may support nationalist constitutional principles at the expense of state autonomy).
} 
with more issues than they possibly could address. Every issue comes with opportunity costs, and the Justices must prioritize. The Justices must make decisions about which issues to consider and which to lay aside. Even a Court composed of Justices generally sympathetic to federalism concerns may well choose not to pursue this opportunity in order to focus its attention on other matters it regards as more pressing or important. Relatedly, in order to initiate significant change, the Justices must have a vision that will be fruitful across a number of cases and will not simply produce doctrinal dead ends. National League of Cities is instructive in this regard, as Rehnquist was never again able to marshal a majority to implement or extend his vision of state sovereignty. ${ }^{148}$

Compared to its predecessors, the Rehnquist Court is particularly interested in issues of constitutional structure. Federalism cases have represented an increasing percentage of the Court's work in recent years. ${ }^{149}$ Federalism long has been a particular interest of the current Chief Justice, who was educated in the western United States and who began his career in Goldwater's Arizona, and federalism has formed a distinctive part of his jurisprudence. ${ }^{150}$ Also from Arizona, but with a political background more deeply rooted in state government, Justice O'Connor also has demonstrated a keen interest in federalism cases. Somewhat surprisingly, through a number of remarkable concurring and dissenting opinions, Justice Thomas has evidenced an interest in a radical rethinking of the Court's federalism jurisprudence. ${ }^{151}$ Justice Scalia's jurisprudential inclinations toward

148. See 1 Laurence H. Tribe, American Constitutional Law 863-73 (3d ed. 2000) (describing the Court's difficulty in applying National League of Cities).

149. LAWrence BAum, The Supreme Court 196-200 (7th ed. 2001) (describing shifts in the Court's agenda).

150. See generally SuE DAVIS, JUSTICE REHNQUiST AND THE CONSTITUTION 135-88 (1989) (describing Rehnquist's "important role" in reviving the federalism debate within the Burger Court); Jeff Powell, The Compleat Jeffersonian: Justice Rehnquist and Federalism, 91 YALE L.J. 1317, 1320-46 (1982) (analyzing Rehnquist's theory of federalism).

151. See United States v. Morrison, 529 U.S. 598, 627 (2000) (Thomas, J., concurring) (encouraging abandonment of the substantial effects test as inconsistent with the original intent of the Framers); Printz v. United States, 521 U.S. 898, 936 (1997) (Thomas, J., concurring) (objecting to the extension of congressional authority over wholly intrastate commerce); Camps Newfound/Owatonna v. Harrison, 520 U.S. 564, 609 (1997) (Thomas, J., dissenting) (criticizing the Court's dormant Commerce Clause jurisprudence as "unmoored from any constitutional text"); U.S. Term Limits, Inc., 514 U.S. at 845 (Thomas, J., dissenting) (describing the origins of the Constitution and the implications for reserved powers); United States v. Lopez, 514 U.S. 549, 584 (1995) (Thomas, J., concurring) (noting that "our case law has drifted far from the original understanding of the Commerce Clause" and should be reconsidered). 
formalism, positivism, and originalism most often have made themselves known in his separation of powers opinions, but they have ready implications for federalism as well. ${ }^{152}$ The current Court not only has the votes to advance the federalism offensive, but also has influential individuals who regard federalism as an important priority and who are willing to exploit opportunities to advance that cause. ${ }^{153}$

Although the Rehnquist Court's federalism offensive is important, its importance should not be overstated. The Court has moved carefully to avoid antagonizing the interests of powerful actors who potentially could threaten the Court's legitimacy. ${ }^{154}$ This conclusion may be surprising, given that this Court has been particularly aggressive in striking down acts of Congress, even though Congress has far more resources with which to strike back at the Court than do the state governments that the Court more often has targeted in the past. ${ }^{155}$ Moreover, the revival of federalism harkens back to the Lochner-era Court and the political repercussions of its resistance to the New Deal. In his dissents, Justice Souter has been particularly direct in reminding the Court of the potential consequences of repeating the errors of the Lochner era. ${ }^{156}$

The current federalism revival is unlikely to lead to Lochner-like consequences, however. The Lochner-era Court did a great many things, and the modern charge that the court is "Lochnerizing" can be similarly broad. For present purposes, however, the Lochner-era Court did something quite specific. In restricting the powers of the national government in the early 1930s, it rendered impossible the central political goals of the newly empowered Democratic Party.

152. See Printz, 521 U.S. at 918-25 (providing a structural analysis of federalism).

153. The possible departure of Chief Justice Rehnquist and Justice O'Connor from the Court in the near future may put the federalism offensive in jeopardy. It seems unlikely that the other three members of the federalism majority would be capable of replacing the leadership of Rehnquist and O'Connor in this area.

154. Congress has made serious challenges to the Court in the past when the latter struck down policies that were particularly important to the legislative majority or its primary constituents. See, e.g., infra note 155 .

155. On Congress's reaction to the Court in prior conflicts, see WALTER F. MURPHY, CONGRESS AND THE COURT 127-241 (1962) (describing Congress's reaction to the Cold War security cases); Gerald N. Rosenberg, Judicial Independence and the Reality of Political Power, 54 REV. POL. 369, 378-83 (1992) (analyzing various instances of judicial retreat in the face of legislative threats).

156. Alden v. Maine, 527 U.S. 706, 814 (1999) (Souter, J., dissenting) (comparing sovereign immunity cases to Lochner); Seminole Tribe v. Florida, 517 U.S. 44, 166 (1996) (Souter, J., dissenting) (warning that the majority has forgotten the lesson of Lochner); United States v. Lopez, 514 U.S. 549, 604 (1995) (Souter, J., dissenting) (same). 
What is most striking about the Court's struggle against Progressivism and the New Deal is not how many laws were struck down or how persuasive the Court's jurisprudence might have been, but how politically salient the Court's actions were. Not since the Dred Scott deci$\operatorname{sion}^{157}$ had the Court claimed that the central mission of an ascendant political coalition was contrary to the basic precepts of the fundamental law of the nation. The Court forced the Democratic Party to undermine the authority of the Court in order to legitimate itself. ${ }^{158}$ More prosaically, the Lochner-era Court effectively prevented Congress and the Roosevelt administration from adopting policies that they regarded as essential to the nation's recovery from the Great Depression and to their own political program. At the same time, the Court's actions were seen as both directly and indirectly blocking similar progressive legislation at the state level, creating a "no-man's land' where no Government-State or Federal—can function." ${ }^{159}$ The Court created an impasse that the other two branches were forced to overcome in order to secure their own electoral survival and the survival of their policies. ${ }^{160}$

Although treading some of the same theoretical ground as the Lochner-era Court, the Rehnquist Court has avoided creating anything like the same political dynamic. The Court's recent Commerce Clause cases are illustrative. It is not yet clear how extensive the implications of the Court's revival of the Commerce Clause as a constraint on the national government will be, and that is a significant distinction between the 1990s and the 1930s. In the 1930s, it very quickly became evident that the Lochner-era Court was not going to accept the First New Deal and that the options for circumventing the Court's constitutional objections were extremely limited. By contrast, the Rehnquist Court has taken pains to minimize the possible implications of its actions. Rather than challenging the post-New Deal jurisprudence on the Commerce Clause, in the Court's opinion in Lopez Chief Justice Rehnquist extensively reviewed the doctrinal history of the Commerce Clause and simply accepted the core doc-

157. Scott v. Sandford, 60 U.S. (19 How.) 393 (1856).

158. For an elaboration of this point, see Keith E. Whittington, Presidential Challenges to Judicial Supremacy and the Politics of Constitutional Meaning, 33 POLITY 365, 383-90 (2001).

159. 5 Franklin D. Roosevelt, The Public Papers AND AdDresses of Franklin D. RoOSEVElT 192 (Samuel I. Rosenman ed., 1938).

160. See generally 2 ACKERMAN, supra note 41, at 255-382 (describing various Courtpacking plans); LEUCHTENBURG, supra note 9, at 82-162 (same). 
trine laid down by the New Deal Court. ${ }^{161}$ Although Lopez gave those doctrines new bite, it is notable that the Court eschewed any claim to doctrinal innovation in this area and implicitly reassured other actors that the central commitments of the New Deal were not up for reconsideration. In particular, the Court did not question whether Congress had authority over all obviously economic activities. The Court reopened the debate over the proper relationship between the state and federal governments, but it did not seek to turn back the clock on the central commitments that the national government has accepted in the twentieth century.

In rejecting a law as beyond the enumerated powers of Congress, the Court did not show the kind of deference to congressional authority that had come to be expected of the post-New Deal Court. In passing the law, Congress at least demonstrated that a majority of its own members approved of the substantive goals of the legislation, ${ }^{162}$ and the representative character of Congress gave at least plausibility to the assumption that popular majorities shared the legislature's views in this regard. Both laws were relatively new when considered by the Court, and thus they were likely to be supported by contemporary majorities. Neither the Gun-Free School Zones Act of $1990^{163}$ nor the Violence Against Women Act of $1994^{164}$ raised the kind of fundamental liberty or democratic representation concerns that have been regarded by some as particularly close to the Court's mission. ${ }^{165}$ The Court seemed to take a substantively countermajoritarian

161. Lopez, 514 U.S. at 555-59 (characterizing the decision as "consistent with the great weight of our case law").

162. Passage of the statute also suggests that a majority of Congress thought that the bill was within their constitutional authority. Especially given the Court's long deference on this front, there is little reason to believe that legislators gave the constitutional issues, as opposed to the substantive issues, much thought. It is at least possible, therefore, that Congress might not be antagonistic to the Court's closer constitutional scrutiny of these statutes. See also Mark A. Graber, Naked Land Transfers and American Constitutional Development, 53 VAND. L. REV. 73, 76, 85-98 (2000) (observing that the "Supreme Court can impose limits on federal power without 'thwarting the will of the actual representatives of the people of the here and now"').

163. 18 U.S.C. $\$ 922(q)$ (1994).

164. 42 U.S.C. $§ 13981$ (1994).

165. See, e.g., United States v. Carolene Prods. Co., 304 U.S. 144, 152 n.4 (1938) (setting forth the conditions that trigger heightened review); see also JESSE H. CHOPER, JUDICIAL ReView AND the National Political Process 60-128, 171-259 (1980) (arguing that the protection of individual rights is the essential function of judicial review); JOHN HART ELY, DEMOCRACY AND DISTRUST 73-179 (1980) (developing a process-based theory of judicial review). 
action in defense of purely formal values, which might be thought to make the Court particularly vulnerable to a political backlash.

Congress passes a wide variety of laws, and not all of them are equally important to legislators or manifest their benefits in the same way. It can be expected that the political reaction to the Court will be strongest when the costs of the Court's actions to elected officials are greatest. Legislators do not always derive political benefit from the actual implementation of legislation. ${ }^{166}$ It may be particularly useful to distinguish between a politician's need for "credit claiming" and his need for "position taking." Credit claiming can be defined as

acting so as to generate a belief in a relevant political actor (or actors) that one is personally responsible for causing the government, or some unit thereof, to do something that the actor (or actors) considers desirable.... The emphasis here is on individual accomplishment ... and on the congressman as a doer. ${ }^{167}$

Credit claiming is politically important, but it is not always applicable. It works best when an individual legislator can credibly claim responsibility for particularized benefits to constituents, such as constituent casework and pork barrel appropriations. ${ }^{168}$ For more general legislation, it is often too difficult for constituents to know whom to credit (or blame) for the legislation itself or for any results, and it is often too difficult for politicians to be able to count on observable results from legislation. ${ }^{169}$ For many issue areas, such as crime, it is almost impossible to determine whether legislation had any effect at all, in which case the politically salient goals are better defined in terms of outputs (e.g., one hundred thousand new policemen on the streets) than results (e.g., reduction in criminal activity).

Position taking, by contrast, does not depend on legislative results. It can be defined as "the public enunciation of a judgmental statement on anything likely to be of interest to political actors. The statement may take the form of a roll call vote." electoral requirement is not that [the congressman] make pleasing

166. See also Neal Devins, Congress as Culprit: How Lawmakers Spurred on the Court's Anti-Congress Crusade, 51 DuKE L.J. 435, 460 (2001) (observing that members of Congress typically have little to gain from bringing forward constitutional objections to bills).

167. DAVID R. MAYHEW, CONGRESS: THE EleCtORAL CONNECTION 53 (1974).

168. Id. at 53-60.

169. See R. Douglas Arnold, The Logic of Congressional Action 44-51, 71-76 (1990) (describing informational difficulties in legislative politics).

170. MAYHEW, supra note 167, at 61. 
things happen but that he make pleasing judgmental statements." ${ }^{171}$ An individual legislator cannot take credit for a piece of general legislation's good effects, or even for its enactment, but he can always take credit for voting the right way on the issue. ${ }^{172}$ Moreover, some legislation is "politically compelling," in that "legislators feel compelled to support certain policy options because the intended effects are popular, irrespective of whether the proposed means will really achieve those ends." ${ }^{173}$ Legislators may be obligated politically to support bills that announce goals such as ending violence against women or creating gun-free schools, but the political benefit that they get for expressing their support for such goals is probably all the political benefit they ever will get from such legislation and perhaps all they desire from it. ${ }^{174}$ Moreover, having supported such legislation in the roll call, they are unlikely to receive any particular blame if the legislation fails for any reason to achieve its goals.

The statutes that the Court reviewed in Lopez and Morrison are clearly of the position-taking type. By the time the Court struck down parts of these laws, legislators already had derived all the political mileage they were going to get from them. Indeed, the Court's actions even provided an opportunity for legislators and other political actors to score a few more political points by being seen denouncing the Court for obstructing attempts to promote the safety of women and children. Furthermore, the Court may have made it slightly more difficult for voters to assign blame to any particular elected official when future episodes of guns in schools or violence against women occur. There is relatively little for legislators to gain from voters, however, by investing political resources in a substantive effort to curb the Court in the aftermath of these cases. The political costs of judicial review were far too small, and the potential political benefits of court curbing are far too uncertain.

\footnotetext{
171. Id. at 62 .

172. Legislators may gain political benefit specifically because of a bill's failure to pass, as when, for example, the president can be blamed for vetoing potentially popular legislation. See JoHn B. GILMOUR, STRATEGIC DisAGREEMENT 119-31 (1995) (analyzing the passage and effect of "veto bait" legislation); Tim Groseclose \& Nolan McCarty, The Politics of Blame: Bargaining Before an Audience, 45 AM. J. POL. SCI. 100, 106-13 (2001) (analyzing legislative bargaining strategies given an audience of voters).

173. ARNOLD, supra note 169 , at 77-78.

174. It should be noted that not all position-taking opportunities are so clear-cut. The right way to vote on a particular piece of legislation depends both on the particular constituency and the framing of the issue (is this an anti-crime measure or a gun control measure?).
} 
These measures are also notable in that they do not represent the central legislative goals of any particular political coalition. The New Deal legislation was central to the Democratic Party's political goals, and the Democratic Party could be expected to take continuing interest in such policies. The interpretations that the 1930s Court gave to the structural features of the Constitution had direct and immediate implications for those legislative goals. In repeatedly striking down such legislation, ${ }^{175}$ the Court placed itself squarely against the interests of the dominant political party of the period. Support for federalism in the 1930s was, quite visibly, opposition to the New Deal. Unsurprisingly, Democratic officials reacted accordingly. Franklin Roosevelt, for example, was explicit in labeling the courts as agents of the "Republican Party." 176 The Rehnquist Court's federalism cases do not follow that pattern. In the present circumstances, the relationship between interpretations of the Constitution's structural features and any particular political agenda is highly contingent and uncertain. To the extent that a constraining interpretation of federalism limits the powers of the national government, then political actors who hope to use the national government to achieve their political objectives may react negatively. But neither political party in the current period has uniform interests in that regard, and the Court is unlikely to impose broad restrictions on federal power. Moreover, the substantive interests at stake in these cases are neither highly salient nor closely identified with any particular political coalition or party. These laws were the product of highly transitory, ad hoc majorities. ${ }^{177}$ Legislative ma-

175. See, e.g., Ashton v. Cameron County Water Improvement Dist. No. 1, 298 U.S. 513, 523-32 (1936) (striking down the Act of May 24, 1934, which provided for the emergency temporary aid of insolvent public debtors, on the grounds that the Act violated state sovereignty); Carter v. Carter Coal Co., 298 U.S. 238, 286-317 (1936) (striking down the Bituminous Coal Conservation Act of 1935 on the ground that the Act exceeded Congress's authority under the Commerce Clause); United States v. Butler, 297 U.S. 1, 57-77 (1936) (determining that certain provisions of the Agricultural Adjustment Act were an unconstitutional assertion of power by Congress); A.L.A. Schechter Poultry Corp. v. United States, 295 U.S. 495, 528-55 (1935) (holding that specific provisions of the National Industrial Recovery Act exceeded Congress's authority under the Commerce Clause); R.R. Ret. Bd. v. Alton R.R. Co., 295 U.S. 330, 348-74 (1935) (holding that the Railroad Retirement Act fell outside the scope of Congress's powers granted by the Commerce Clause); Panama Ref. Co. v. Ryan, 293 U.S. 388, 414-30 (1935) (invalidating certain executive orders and regulations promulgated under the National Industrial Recovery Act on the grounds that they exceeded constitutional limits on Congress's delegation of power).

176. 1 Franklin D. Roosevelt, The Public Papers and Addresses of Franklin D. ROOSEVELT 837 (Samuel I. Rosenman ed., 1938).

177. Legislative majorities in Congress are usually stable and party-based. Occasionally, for example on distributional issues such as transportation bills, legislation arises out of an ad hoc 
jorities were mobilized to pass these statutes in the first instance, but no organized majorities stand behind them. As a result, these cases do not create or antagonize any distinctive opposition to the Court. As stand-alone issues, they are not important enough to justify sustained political resistance to the Court. At the same time, they are not part of any integral political package. The Court's recent federalism decisions had no particular implication for any broad legislative agenda, and thus no broader coalition was mobilized by the results in these individual cases. In contrast to such issues as civil rights or abortion, there is no coherent "federalism" lobby or interest. Politically, the immediate losers in the Court's federalism cases will remain isolated, unless and until the cases have more foreseeable negative consequences for a wider range of interests.

Mounting a serious campaign against the Court requires substantial political resources and numerous committed allies who must see their own interests as threatened by the Court. In striking down New Deal legislation, the 1930s Court was confronting precisely that kind of mobilized coalition. Even then, however, the Court was capable of deflecting the administration's Court-packing plan by defusing organized labor's opposition to the Court with a favorable ruling in NLRB v. Jones \& Laughlin Steel Corp. ${ }^{178}$ Conversely, the segregationists who were outraged by Brown v. Board of Education ${ }^{179}$ were hapless until they could make common cause with anti-Communists offended by the Court's actions in $1957 .{ }^{180}$ The Warren Court was subsequently more cautious in picking its opponents. ${ }^{181}$

The Court can expect to strike down laws such as those at stake in Lopez and Morrison with few political consequences. Although crime is an important bipartisan issue, it is too nebulous to support mobilization against the Court over these two statutes. Moreover, as a federalism issue, the public tends to regard crime as an issue better

coalition of legislators that organizes largely outside normal party channels and only for the sake of the passage of that single bill.

178. 301 U.S. 1, 29-43 (1937) (upholding the National Labor Relations Act as a valid exercise of Congress's powers under the Commerce Clause); see also Gregory A. Caldeira, Public Opinion and the U.S. Supreme Court: FDR's Court-Packing Plan, 81 AM. POL. SCI. REv. 1139, 1148 (1987) (tracking the collapse of public support for President Roosevelt's Court-packing plan).

179. 347 U.S. 483 (1954).

180. See PowE, supra note 88, at 93-102 (describing the national security cases of 1957 and the coalescing of opposition to the Court).

181. See id. at 127-43 (describing congressional reaction to certain Warren Court decisions and the Court's response). 
addressed at the local level, in keeping with the Justices' own instincts in these cases. ${ }^{182}$ As such, the Court is unlikely to be seen as seriously hampering crime control with these decisions.

The recent case of Solid Waste Agency v. United States Army Corps of Engineers ${ }^{183}$ raised a more difficult problem for the Court, and, consistent with this analysis, the Court advanced the federalism offensive, but even more carefully. Solid Waste Agency involved the regulatory interpretation of the Clean Water Act by the Army Corps of Engineers, in particular the "migratory bird rule" that extends the Corps's authority to include intrastate waters that provide habitat for migratory birds. ${ }^{184}$ Unlike crime, environmental protection is commonly regarded as an appropriate function of the national government. ${ }^{185}$ As a regulatory function with continuing political support, environmental protection shares the centralizing biases of the positive state. ${ }^{186}$ The Corps's understanding of federally regulated waters tested the Rehnquist Court's willingness to constrain the post-New Deal state. The facts of the case raised the possibility that the Court might extend its Lopez logic to further advance its federalism offensive. ${ }^{187}$ Although the migratory bird rule is relatively minor and of limited political visibility, any constitutional action in this case necessarily would hold implications for the broader range of federal environmental regulation, which carries substantial political importance. Unlike most criminal issues, environmental issues have an array of organized and stable interests behind them. Environmental legislation

182. Pew Research Center Poll of January 9, 1997, Roper Center, at http://web.lexis-nexis. com/universe (last visited Aug. 23, 2001) (accession number 0270891) (on file with the Duke Law Journal) (demonstrating that the public has more trust and confidence in state and local governments to fight crime relative to the federal government by a two-to-one margin).

183. 531 U.S. 159 (2001).

184. Id. at 162-66 (describing the genesis of the migratory bird rule under Section 404(a) of the Clean Water Act, 33 U.S.C. \$ 1344(a) (1994)).

185. Post-Modernity Project at the University of Virginia Poll of January 27, 1996, Roper Center, at http://web.lexis-nexis.com/universe (last visited Aug. 23, 2001) (accession number 0280232) (on file with the Duke Law Journal) (reporting that members of the public regard the protection of the natural environment to be mainly the responsibility of the national government by a two-to-one margin).

186. See Whittington, supra note 81 , at 493-500 (discussing how regulatory activities create a centralizing bias).

187. The migratory bird rule extended federal jurisdiction beyond navigable waterways that could be used for interstate commerce to isolated, intrastate bodies of water, potentially absorbing traditional state authority over land-use planning and without an adequate showing of a substantial effect on interstate commerce of such regulated activities. Moreover, the activity being regulated - the filling of such bodies of water-may, in many cases, be noncommercial in nature. 
is a central feature of the liberal surge of the late 1960s and early 1970 s, and it continues to attract substantial political support. ${ }^{188}$ Environmentalism also tends to be largely a position-taking issue, but the interest groups that attend to environmental issues force lawmakers to engage in greater policy activity for their position taking to be credible. $^{189}$ In sum, striking at environmental regulation would give greater policy significance to the Court's federalism offensive, but it also would heighten the political costs of these decisions to voters and legislators and, therefore, possibly, to the Court.

Faced with these possibilities, the Court made a strategic compromise-rejecting the broad interpretation of the Act by the Corps, while deferring the constitutional judgment of that broad interpretation. ${ }^{190}$ Rather than escalating the conflict to the constitutional level, the Court shifted the burden back to Congress. ${ }^{191}$ The Court increased the difficulty of achieving the policy favored by the Corps, since it now must be reestablished by the positive and explicit action of (a possibly Republican) Congress. ${ }^{192}$ If Congress is able to agree on legislation reestablishing a similar rule, the Court will have another opportunity to consider the constitutional issue-but this time with a better measure of the political costs of doing so. The Court has clearly signaled its constitutional and policy concerns to the other branches and to the lower courts while minimizing any political backlash, since the responsibility for the final policy has been placed squarely in the hands of the legislature. The Court has refrained from creating a con-

188. See MARC Allen Eisner, Regulatory Politics in Transition 118-53 (1993) (describing the rise of "new social regulation").

189. ARNOLD, supra note 169 , at 64-68.

190. Solid Waste Agency v. United States Army Corps of Eng'rs, 531 U.S. 159, 172-74 (2001) ("We thus read the statute as written to avoid the significant constitutional and federalism questions raised by respondents' interpretation.").

191. Id. at 172-73 ("Where an administrative interpretation of a statute invokes the outer limits of Congress' power, we expect a clear indication that Congress intended that result.").

192. The U.S. Army Corps of Engineers had interpreted the Clean Water Act's requirement for federal landfill permits for projects involving "navigable waters" to include waters that served as habitat for migratory birds. In regard to an abandoned gravel pit that neither was a navigable water nor adjoined navigable waters, the Court held the Corps's interpretation was clearly grounded in neither the statutory text nor the legislative intent. Given an administrative interpretation that "alters the federal-state framework by permitting federal encroachment upon a traditional state power," the Court required a clear "indication that Congress intended that result." Id. at 167-73; see also WILliAM N. ESKRIDGE, JR., DYNAMIC STATUTORY INTERPRETATION 74-80 (1994) (analyzing statutory interpretation as an anticipated response game); William N. Eskridge, Jr. \& Philip P. Frickey, Foreword: Law as Equilibrium, 108 HARV. L. REV. 26, 30-42, 56-57 (1994) (analyzing law as a product of strategic interaction). 
stitutional impasse and thereby has diverted political opposition away from itself, while still placing obstacles in the way of centralization. ${ }^{19}$

\section{CONCLUSION}

Over the past decade, the Court has revived federalism as an active constraint on the power of the national government after a halfcentury of near disuse. The possibility of the Court relying on the Commerce Clause to strike down an act of Congress would have seemed ridiculous in the immediate aftermath of the consolidation of the New Deal constitutional order, and it would have seemed highly unlikely even a decade ago. Before the recent federalism revival, it generally was admitted-in a nod to the plain constitutional textthat there were theoretical limits to the authority of the national government, ${ }^{194}$ but it was hard to imagine any of those limits being encountered in judicial practice. The Rehnquist Court now has claimed, not just once but several times, across a range of cases, that Congress in fact has exceeded those limits. Although it remains to be seen how long and how far the Court can and will sustain this federalism offensive, the campaign thus far has been quite significant.

But how should it be explained? Ultimately, it must be explained in a fashion that takes account of both politics and law. A purely legal explanation would have difficulty accounting for the timing and form of the Court's changing constitutional interpretation. A purely political explanation would neglect the particular institutional features of the Court and its deep concern for the law. The Court must make decisions within a particular social and political environment; it is not immune to the effects of that environment. That environment condi-

193. The Court's sovereign immunity cases represent another avenue for reasserting federalism values while minimizing political backlash. See, e.g., Bd. of Trs. of the Univ. of Ala. v. Garrett, 531 U.S. 356, 121 S. Ct. 955, 962 (2001) (holding that suits against states under the Americans with Disabilities Act are barred by the Eleventh Amendment); Kimel v. Fla. Bd. of Regents, 528 U.S. 62, 80-91 (2000) (determining that suits against states under the Age Discrimination in Employment Act are barred by the Eleventh Amendment). Within the context of sovereign immunity, the Court can address more politically important legislation involving, for example, age or disability discrimination precisely because the policy consequences of the Court's actions are relatively small (the larger set of claims against private employers are left in place) and legislative responses remain available (through action by the state governments).

194. See Maryland v. Wirtz, 392 U.S. 183, 196 (1968) ("This Court has always recognized that the power to regulate commerce, though broad indeed, has limits."); Santa Cruz Fruit Packing Co. v. NLRB, 303 U.S. 453, 466 (1938) ("The expansion of enterprise has vastly increased the interests of interstate commerce but the constitutional differentiation still obtains."). 
tions how judges, as well as other political actors, think about politics and the law. That environment also can limit what actions the Court practically can take.

Consistent with recent conservative intellectual and legal thought, a majority of the Justices on the current Court believe that the constitutional constraints on the national government imposed by the federal structure are more extensive than was commonly accepted in the immediate postwar period. Whether fully consistent with the original Constitution or not, there was a clear ideological and political rationale for greater centralization of government authority in the early twentieth century. ${ }^{195}$ That rationale is no longer central to contemporary American politics. To some degree, this makes the national government less relevant to American life than it once was. To some degree, this means that some actions the national government takes will be hard to justify in terms of the old rationales. To a skeptical Court, excesses of centralization will not be hard to find. Moreover, as excesses, the political support for such policies can be thin. Statutes that are struck down are no longer-as they were during the New Deal-necessary measures to cure the ailments of the national economy; they are more likely to be politically expedient responses to the passions of the moment. These statutes respond to the sorts of transitory pressures the Court is less likely to feel and integrate into its constitutional decisionmaking.

The Lopez Court is not the Lochner Court. Substantively, the Lopez Court is more developmental than reactionary, feeling its way toward a distinctly post-New Deal decentralization of the federal system. Politically, the Lopez Court is swimming with the political current rather than against it, and the Court has given no indication of wanting to challenge central commitments of dominant political actors. Nonetheless, the Lopez Court has been unusually active in striking down acts of Congress and reorienting constitutional law. In doing so, the Court has been an autonomous agent of constitutional change. The Court has seized the political opportunities that have presented themselves to advance the Court's own understanding of the Constitution. The Court has been opportunistic. ${ }^{196}$ It has not at-

195. See Whittington, supra note 81 , at 490-503 (arguing that the interaction of political movements and events in the early twentieth century favored centralization of the federal government).

196. See Eskridge \& Frickey, supra note 192, at 43 (characterizing the current Court as "risk-averse"); Mark Tushnet, Foreword: The New Constitutional Order and the Chastening of 
tacked the still-vital center of the New Deal constitutional consensus, but rather has taken advantage of a softening at the margins of the New Deal regime. The Court is not alone in doing so. But along with other political actors, the Rehnquist Court is participating in a political process of constitutional change.

Constitutional Aspiration, 113 HARV. L. REV. 29, 63-76 (1999) (characterizing the current Court as administratively and substantively downsized). 